\title{
The Effect of Pandemic News on Stock Market Returns During the Covid-19 Crash: Evidence from International Markets
}

\section{Covid-19 Çöküşü Sırasında Salgın ile ilgili Haberlerin Borsa Getirileri Üzerindeki Etkisi: Uluslararası Piyasalar Örneği}

\author{
Ömer Faruk TAN ${ }^{1}$ (])
}

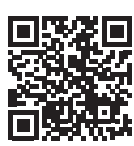

'Res. Asst. Dr., Marmara University, Faculty of Business Administration, Department of Accounting and Finance, İstanbul, Turkey

ORCID: Ö.F.T. 0000-0002-8875-4696

Corresponding author/ Sorumlu yazar: Ömer Faruk Tan, Marmara Üniversitesi, İşletme Fakültesi, İstanbul, Türkiye

E-mail/E-posta:

omer.tan@marmara.edu.tr

Received/ Geliş tarihi: 22.02.2021

Revision Requested/Revizyon talebi: 04.05.2021 Last revision received/Son revizyon teslimi: 28.05.2021

Accepted/Kabul tarihi: 29.05.2021

Citation: Tan, Ö. F. (2021). The effect of pandemic news on stock market returns during the Covid-19 crash: Evidence from international markets. Connectist: Istanbul University Journal of Communication Sciences, 60, 217-240. https://doi.org/10.26650/CONNECTIST2021-884955

\begin{abstract}
This study investigates the effect of pandemic-related news on stock market returns in international markets using the quantile regression method. The media hype index, fake news index, country sentiment index, infodemic index, and media coverage index provided by the RavenPack data platform are used for the analysis. In this research, 2,996 observations from 80 countries, consisting of daily data from January 22, 2020, to April 17, 2020, were used. The results show that the impact of Covid-19-related news on market returns varies among the quantiles of the stock market; in other words, there is an asymmetric dependency between the news and financial markets. With the increase in coverage about the pandemic in the media, the negative impact on market returns exhibits a decreasing trend from low quantiles to high quantiles. More intense use of effective communication channels is required to alleviate the financial crash caused by Covid-19. To capture the effect of the news on financial markets, this analysis also categorized countries according to the Morgan Stanley Classification Index ( $\mathrm{MSCl}$, n.d.), such as by developed, emerging, standalone, and frontier markets and by geographical location, including Europe, Africa, North and South America, Asia, and the Middle East. The results are consistent with the previous findings and the dependency between the news and financial markets remains asymmetric.
\end{abstract}

Keywords: Covid-19, financial markets media hype index, country sentiment index, media coverage index, quantile regression

JEL Codes: F65, G40, D53 
Öz

Bu çalışma salgın haberlerinin uluslararası piyasaların getirileri üzerindeki etkisini kantil regresyon yöntemi kullanarak araştırmaktadır. Analiz için RavenPack veri platformu tarafından sağlanan medyatiklik endeksi, sahte haber endeksi, ülke duyarlılık endeksi, infodemi endeksi ve medya ilgi endeksi kullanılmıştır. Bu araştırmada 22 Ocak 2020'den 17 Nisan 2020'ye kadar günlük verilerle 80 ülkeden 2.996 gözlem kullanılmıştır. Analiz sonuçlarına göre Covid-19 ile ilgili haberlerin piyasa getirileri üzerindeki etkisinin kantiller arasında farklılık gösterdiğini, diğer bir deyişle haberler ve finansal piyasalar arasında asimetrik bir bağımlılık bulunmuştur. Medyada salgın ile haberlerin artmasıyla birlikte piyasa getirileri üzerindeki olumsuz etkisi düşük kantillerden yüksek kantillere doğru düşüş eğilimi göstermektedir. Covid-19'un neden olduğu finansal çöküşü hafifletmek için etkili iletişim kanallarının daha yoğun kullanılması gerekmektedir. Haberlerin finansal piyasalar üzerindeki etkisini yakalamak için, bu çalışma aynı zamanda ülkeleri Morgan Stanley Sınıflandırma İndeksine göre (MSCl, n.d.), gelişmiş, gelişmekte olan, sınır pazarları ve bağımsız pazarlar olarak ve coğrafi konumuna göre Avrupa, Kuzey ve Güney Amerika, Asya ve Ortadoğu ülkeleri olarak sınıflandırmıştır. Sonuçlar önceki bulgular ile tutarlılık göstermiş ve haberler ile finansal piyasalar arasındaki asimetrik bağımlılık sürmüştür.

Anahtar Kelimeler: Covid-19, uluslararası finansal piyasalar medyatiklik endeksi, ülke duyarlılık endeksi, medya ilgi endeksi, kantil regresyon

JEL Sınıflandırılması: F65, G40, D53

\section{INTRODUCTION}

The novel coronavirus that first appeared in December 2019, referred to simply as "Covid-19," rapidly evolved into a global pandemic, posing significant health and economic difficulties (Ahundjanov, Akhundjanov, \& Okhunjanov, 2020, p. 1). The first confirmed death in China was announced on January 11, 2020. After the first cases in the United States and Western Europe were confirmed at the end of January 2020, the total number of cases soared dramatically, especially in March. On March 11, 2020, the World Health Organization (WHO) declared a pandemic and warned countries to take precautions. The pandemic's threat has prompted people to alter their usual habits and governments to take extraordinary steps, such as issuing stay-at-home orders and travel bans, closing schools and businesses, mandating masks, and imposing similar restrictions (Ahundjanov et al., 2020; Chen et al., 2020; Nicola et al., 2020; Zaremba et al., 2021) that have caused global economic downturns (Yilmazkuday, 2020) and crashes in financial sectors (Baker et al., 2020). Stock markets, especially in the U.S, Japan, Germany and the U.K, experienced a collapse of around 10\%-20\% (Akhtaruzzaman, Boubaker, \& Sensoy, 2020; Ali, Alam, \& Rizvi, 2020; Ashraf, 2020b; Zhang, Hu, \& Ji, 2020). On March 16, the volatility index of the Chicago Board Options Exchange, known as the VIX, reached its all-time high (Wagner, 2020).

Covid-19-related news and information have since appeared widely in the media, and investors make their investment decisions based on the information generated. 
Disease-related news can trigger panic and affect investor sentiment (Tetlock, 2007). Political and economic news in the media is essential to share prices (Broadstock \& Zhang, 2019; Shi \& Ho, 2020). Social media news has a major effect on share prices, especially during a time of political and economic uncertainty (Cepoi, 2020). The economic significance and effects of such information in times of unparalleled access to news and information are difficult for investors to reasonably evaluate (Haroon \& Rizvi, 2020). García (2013) reveals that the negative or positive tone of reporting in financial columns in the New York Times affects daily stock returns in recession times and Hanna, Turner, \& Walker (2020) reveal that the tone of the Financial Times impacts trading volume during bull markets. Groß-Klußmann \& Hautsch (2011) and Smales (2014b) demonstrate that negative news has a greater impact than positive news; Dzielinski (2011) shows that negative (positive) news causes below (above) average market returns.

This study tries to contribute to the literature by investigating the influence of Covid-19-related news on international stock markets. It reveals that there is an asymmetric dependence between news and stock returns by applying the quantile regression method. The few existing studies in the literature examine the U.S. and European stock markets (Cepoi, 2020; Corbet et al., 2020; Haroon \& Rizvi, 2020); this study includes the stock market returns of 80 countries. The purpose of the paper is to fill the gap that exists in the literature.

Several studies focus on the effect of Covid-19 on financial markets, such as the impact on stock market returns and volatility (Al-Awadhi et al., 2020; Albulescu, 2020; Ali et al., 2020; Ashraf, 2020b, 2020c; Bahrini \& Filfilan, 2020; Contessi \& Pierangelo, 2020; Gu et al., 2020; Harjoto et al., 2020; Kartal, Kılıç-Depren, \& Depren, 2020; Mazur, Dang, \& Vega, 2020; Rababah et al., 2020; Sergi et al., 2021; Thorbecke, 2020; Topcu \& Gulal, 2020), trade volume (Chiah \& Zhong, 2020; Harjoto et al., 2020), stock repurchases (Pirgaip, 2021), government responses or interventions (Ashraf, 2020a; Chen et al., 2020; Zaremba et al., 2020; Zaremba et al., 2021), contagion effect (Okorie \& Lin, 2020), market illiquidity (Baig et al., 2020), tourism and leisure sectors (Karabulut et al., 2020; Ghosh, 2020; Kaczmarek et al., 2021), herding behavior (Chang, McAleer, \&Wang, 2020; EspinosaMéndez \& Arias, 2020), cryptocurrencies (Conlon \& McGee, 2020; Corbet, Larkin, \& Lucey, 2020; Demir et al., 2020), mutual funds (Mirza et al., 2020; Yarovaya et al., 2021), dividends (Krieger, Mauck, \& Pruitt, 2020; Mazur, Dang, \& Vo, 2020), uncertainty (Jeris \& Nath, 2020), housing prices (Qian, Qiu, \& Zhang, 2021) and oil prices (Corbet, Goodell, 
\& Günay, 2020; Devpura \& Narayan, 2020; Fu \& Shen, 2020; Huang \& Zheng, 2020; Salisu, Ebuh, \& Usman, 2020).

Among the studies related to the impact of pandemic news, Cepoi (2020) examines stock market responses to Covid-19-related news in the six most affected developed markets (France, Germany, Italy, Spain, the U.S. and the U.K.) and finds that the news has an asymmetric effect on financial markets. Ambros et al., (2020) use 30-minute news and market data to capture the impact of the Covid-19-related news on financial markets. While the news about Covid-19 does not have an impact on returns, it is found to have a significant effect on volatility. Salisu \&Vo (2020) examine the effect of pandemicrelated health news on the stock markets of 20 countries. Health news and Volatility Index (VIX) predictability results combine impact returns negatively. Corbet et al., (2020) analyze the stock performances of firms with the word "corona" in their brands or product names (Constellation Brands Inc. [U.S.], Corona Corp. [Japan], and Coronation Fund Managers [South Africa]. The results of the study indicate that the stock prices of these firms are affected negatively on the whole. Haroon \& Rizvi (2020) investigate the effect of coronavirus-related news on the volatility of equity markets for the world, the U.S and sub-sectors. The rising panic index creates volatility for the world, the U.S. and within some sectors of the U.S, specifically: energy, travel, leisure, automobiles \& components and transportation. A negative sentiment index induces volatility in the U.S. market, and, interestingly, higher media coverage in global markets is correlated with lower volatility. To summarize the studies examining the impact of the Covid-19related news on markets, it can be seen that the news has an effect on market returns and volatility in general.

\section{AIM AND METHODOLOGY}

This part of the study will explain the purpose of the study, and then the methodology, and finally the data collection.

\section{Aim}

The panic atmosphere that occurred with the spread of Covid-19 all over the world affected not only social life but also the decisions of financial investors. In this paper, the effect of the Covid-19-related news on international markets is analyzed with the quantile regression method to analyze whether the effect of the news on different quantiles is symmetrical or not. 


\section{Methodology}

Based on the conditional mean function $E(y \mid x)$, the classical regression model analyzes the relationship between an independent $(x)$ and a dependent variable $(y)$. Therefore, based on a moment of the distribution of $y$, this model provides a relatively limited measure of the relationship (Barış-Tüzemen, Tüzemen, \& Çelik, 2020, p. 20792-20793). The Ordinary Least Square (OLS) estimators lose their effectiveness when the errors are not suitable for normal distribution and contain outliers. In some situations, the quantile varying estimations disclose that OLS approaches cannot ensure a solution for extreme events. Considering the excess volatility during the Covid-19 turmoil, the quantile regression model was employed in this study. In contrast to other econometric techniques that primarily focus on mean effects, the quantile regression is the technique most often used for handling with the fat tails or extreme values in asset return distributions (Cepoi, 2020; du Plooy, 2019). The quantile regression model was first suggested by Koenker \& Basset (1978) and applied to cover a set of regression curves that differ across different quantiles of the dependent variable's conditional distribution. The advantages of quantile regressions are as follows:

- This technique is more adaptable for modeling data with heterogeneous conditional distributions.

- In comparison to mean regression, median regression is more robust to outliers.

- This method can seize the potential nonlinear relationship between independent and dependent variables, which cannot be solved using other linear approaches.

It can be written as the basic quantile model in equation (1):

$$
Y_{i=x_{i}^{\prime}}^{\prime} \beta \tau+\mu \tau_{i} \text { with } Q \tau\left(y_{t} \mid x_{t}\right)=x_{t}^{\prime} \beta \tau
$$

where, $x_{t}^{\prime}$ vshows a vector of regressors, $\beta \tau$ displays the vector of parameters to be

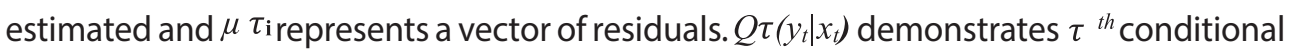
quantile of $\boldsymbol{y}_{i}$ granted $x_{i}^{\prime}$. The approximation of is supported by the undermentioned optimization problems:

$\beta \tau=\operatorname{argmin} \beta$

$0<\tau<1$

$$
\left\{\sum_{t: y t>x_{t}^{\prime} \beta} \tau\left|y i-x_{i}^{\prime} \quad\right|+\sum_{t: y t>x_{t}^{\prime} \beta}(1-\tau)\left|y_{i}-x_{i}^{\prime} \beta\right|\right\}
$$


The median regression is received by $\tau=0.5$. Different quantiles of conditional distribution can be found through variations of (Chellaswamy, Natchimuthu, \& Faniband, 2020, p. 149).

\section{Data Collection}

The data of the indices were acquired from the Thomson Reuters DataStream. If the data is not available on this platform, it can be obtained from https://www.investing. com (Investing, n.d.). The data from the Trinidad \& Tobago Stock Exchange, however, can only be retrieved from their own website (Trinidad \& Tobago Stock Excange, n.d.). The study period lasted from January 22, 2020, to April 17, 2020, with daily data being used. The reason for making the last day April 17 is that although as of mid-April the uncertainty was still continuing, the stock markets had started to recover to a certain extent (Cepoi, 2020). The financial market indices of 80 countries were used in the study, as shown in Table 1. After eliminating weekend holidays, countries' national holidays and incomplete data sets, the final data consisted of 2,296 observations. The sample data was also classified into 1,113 observations across 24 developed markets, 1,066 observations across 27 emerging markets, 561 observations across 18 frontier markets, and 256 observations across 11 standalone and unclassified markets. The Covid-19-related news variables were obtained from RavenPack. This data analytics platform provides the latest information about panic, sentiment and misinformation regarding coronavirus measures. The platform has a country-specific media hype index, fake news index, country sentiment index, infodemic index and media coverage index (Blitz et al., 2020; Cepoi, 2020; Shi \& Ho, 2020; Smales, 2014a). The description of each index is given in the appendix.

\section{FINDINGS}

The descriptive statistics of the variables used in the study are shown in Table 2. The average returns are -0.004 with a standard deviation of 0.0405 . A zero mean value endorses the random walk property of stock market returns (Ashraf, 2020a, p. 4). All indices except the country sentiment index assign values between 0 and 100. An increase in value means that news about Covid-19 is getting more coverage in the media. The sentiment index, on the other hand, assigns a value between -100 and 100, and when it approaches 100, the improving sentiment positively affects returns. The infodemic index shows the highest values, while the fake news index has the lowest average values and standard deviation. 
Table 3 shows the correlation matrix table. Stock returns have negative and significant correlations with media hype, infodemic and media coverage index, and negative but insignificant correlation with fake news index. In contrast, as expected, it has a positive and significant correlation with the country sentiment index. Variance inflation factor (VIF) displays the multicollinearity problem among the independent variables. In the respective regression model, multicollinearity is considered too high if the VIF is larger than 5 or 10 (Guizani, 2017, p. 139). In our study, the mean VIF was 2.09, so there is no multicollinearity problem among variables.

Table 4 indicates the quantile regression results for all countries from the 0.05 to 0.95 quantiles. The media hype index has a negative effect on stock returns, but the magnitude of the effect decreases from the lowest to the upper quantiles. It has a negative and significant impact on stock returns between the 0.05 and 0.25 quantiles. The fake news index does not affect market returns at times of extremely bearish (the 0.05 quantile) and bullish (0.95) markets and, interestingly, stock returns indicate the positive influence over time of financial turbulence for the 0.10 and 0.25 quantiles (Cepoi, 2020). When good news about the coronavirus circulates in a given country, the sentiment index of the country is positively affected for the lower quantiles. Interestingly however, the sentiment index influences the highest quantile negatively but insignificantly. The infodemic index is the only one that has a negative and significant effect on all quantiles. In addition, the media coverage index has a negative effect on stock returns, but an insignificant one, for the 0.90 and 0.95 quantiles. Fang \& Peress (2009) finds that stocks with no media coverage have a higher return than stocks with higher media coverage and suggests that the extent of information propagation affects stock returns. Stock market returns are affected by the coverage of Covid-19-related news in the media and the increase in coverage of entities (Cepoi, 2020; Haroon \& Rizvi, 2020). Figure 1 illustrates the graphical results of each variable.

This analysis also categorized markets based on the MSCl classification system (https://www.msci.com/market-classification) to examine the effect of the news on different financial markets. Table 5 shows the results in the developed, emerging, and frontier markets, respectively. The results in standalone and unclassified markets are shown in the Appendix. The findings are similar to those mentioned above, as identifying an asymmetric dependency between the indices and market returns. The country sentiment index has a positive effect on developed markets for the 0.90 and 0.95 quantiles and the index is positive and significant for emerging and frontier markets 
for the lower quantiles ( 0.05 and 0.10$)$. The media coverage index has a negative and significant effect on developed and emerging markets. Except for the 0.50 and 0.75 quantiles, the media hype index has a negative and significant effect on stock returns for emerging markets. Finally, this analysis categorizes countries according to their geographical regions based on $\mathrm{MSCl}$ classification. Table 6 displays the results for Europe, the Americas (North and South America), Asia, Africa and the Middle East, respectively. The results are in line with those previously mentioned. Furthermore, the robustness is tested by conducting equal testing among the different quantile levels for international markets and other sub-groups. Because of the brevity of the study, only the results for international markets have been reported. Table 7 displays the F-tests results for each pair of quantile levels. The results of the test reject the null hypothesis that the coefficients of each quantile level are equal or homogeneous. These findings demonstrate that each independent variable has different effects on the dependent variables (Nguyen, 2020).

\section{DISCUSSION AND CONCLUSION}

In this information age, people can be bombarded with a large amount of true or false news from different media channels. The Covid-19 pandemic, which emerged as of the end of December 2019, 100 years after the Spanish flu, dramatically spread all over the world and has created chaos. The presence of both true or false information in the news about what the disease is, how it is transmitted, and whether a vaccine would be developed or not has affected not only social and economic life, but also the rational decisions of investors. As a result, since not all investors could access the most accurate information at the same time, as investors sold in a panic, volatility increased, and returns were negative. Especially as of the end of January 2020, with the virus having spread to the whole of the U.S and Europe, the financial markets experienced unprecedented declines, then started to recover from mid-April thanks to the support governments gave to the markets. This study attempts to examine the impact of pandemic-related news on stock returns in international markets from January 22, 2020 , to April 17, 2020, with a sample of 2,996 observations across 80 countries. The media hype index, fake news index, country sentiment index, infodemic index, and media coverage index provided by the RavenPack data platform were used to capture the effect of the news on international markets. This paper demonstrates that the effect of the news on stock returns varies amongst the quantiles. In other words, there is an asymmetric dependency between the news and market returns. The results of the 
study are consistent with the findings of Cepoi (2020). An equality test is also applied to confirm the results, and the impact is not found to be homogenous on quantiles. According to the results, it can be interpreted those investors in international markets react at different levels to the Covid-19-related news. Furthermore, the speed at which markets respond to news might indicate policy implications in terms of assuring welltimed dissemination of news to all market participants (Smales, 2014). In conclusion, to alleviate the financial turmoil associated with Covid-19, more extensive use of proper communication channels is needed. Since this study is limited to the effect of pandemicrelated news on international market returns, future papers might analyze the impact of the pandemic on volatility and volume with different techniques for examining international or other sub-markets by adding country-specific variables.

\section{ENDNOTES}

${ }^{1}$ Although China had Covid-19 cases before 22.01.2020, databases started reporting information on this day.

${ }^{2}$ Australia, Austria, Belgium, Canada, Chile, Czech Republic, Colombia, Denmark, Estonia, Finland, France, Germany, Greece, Hungary, Ireland, Iceland, Israel, Italy, Japan, Korea, Latvia, Lithuania, Luxembourg, Mexico, Netherlands, New Zealand, Norway, Poland, Portugal, Slovak Republic, Slovenia, Spain, Switzerland, Sweden, Turkey, United Kingdom, United States

Peer-review: Externally peer-reviewed.

Conflict of Interest: The author has no conflict of interest to declare.

Grant Support: The author declared that this study has received no financial support.

\section{REFERENCES}

Ahundjanov, B. B., Akhundjanov, S. B., \& Okhunjanov, B. B. (2020). Information search and financial markets under Covid-19. Entropy, 22(7), 1-18. https://doi.org/10.3390/e22070791

Akhtaruzzaman, M., Boubaker, S., \& Sensoy, A. (2020). Financial contagion during COVID-19 crisis. Finance Research Letters. https://doi.org/10.1016/j.frl.2020.101604

Al-Awadhi, A. M., Alsaifi, K., Al-Awadhi, A., \& Alhammadi, S. (2020). Death and contagious infectious diseases: Impact of the Covid-19 virus on stock market returns. Journal of Behavioral and Experimental Finance, 27, 1-5. https://doi.org/10.1016/j.jbef.2020.100326

Albulescu, C. T. (2020). Covid-19 and the United States financial markets'volatility. Finance Research Letters, (July). https://doi.org/10.1016/j.frl.2020.101699 
Ali, M., Alam, N., \& Rizvi, S. A. R. (2020). Coronavirus (Covid-19) - An epidemic or pandemic for financial markets. Journal of Behavioral and Experimental Finance, 27, 1-6. https://doi.org/10.1016/j.jbef.2020.100341

Ambros, M., Frenkel, M., Huynh, T.L.D., \& Kilinc, M. (2020). Covid-19 pandemic news and stock market reaction during the onset of the crisis: Evidence from high-frequency data. Applied Economics Letters, 1-4. https://doi. org/10.1080/13504851.2020.1851643

Ashraf, B. N. (2020a). Economic impact of government interventions during the Covid-19 pandemic: International evidence from financial markets. Journal of Behavioral and Experimental Finance, 27, 100371. https://doi.org/10.1016/j.jbef.2020.100371

Ashraf, B. N. (2020b). Stock markets' reaction to Covid-19: Cases or fatalities? Research in International Business and Finance, 54, 1-7. https://doi.org/10.1016/j.ribaf.2020.101249

Ashraf, B. N. (2020c). Stock markets' reaction to Covid-19: Moderating role of national culture. Finance Research Letters, 1-20. https://doi.org/10.1016/j.frl.2020.101857

Bahrini, R., \& Filfilan, A. (2020). Impact of novel coronavirus on stock market returns: Evidence form GCC countries. Quantitative Finance and Economics, 4(4), 640-653. https://doi.org/10.1191/146342301682157692

Baig, A. S., Butt, H. A., Haroon, O., \& Rizvi, S. A. R. (2020). Deaths, panic, lockdowns and US equity markets: The case of Covid-19 pandemic. Finance Research Letters, (July). https://doi.org/10.1016/j.frl.2020.101701

Baker, S. R., Bloom, N., Davis, S. J., Kost, K. K., Sammon, M. C., \& Viratyosin, T. (2020). The Unprecedented Stock Market Impact of Covid-19. NBER Working Paper. No. 26945.

Barış-Tüzemen, Ö., Tüzemen, S., \& Çelik, A. K. (2020). Does an N-shaped association exist between pollution and ICT in Turkey? ARDL and quantile regression approaches. Environmental Science and Pollution Research, 27(17), 20786-20799. https://doi.org/10.1007/s11356-020-08513-w

Blitz, D., Huisman, R., Swinkels, L., \& van Vliet, P. (2020). Media attention and the volatility effect. Finance Research Letters, 36, 1-6. https://doi.org/10.1016/j.frl.2019.101317

Broadstock, D. C., \& Zhang, D. (2019). Social-media and intraday stock returns: The pricing power of sentiment. Finance Research Letters, 30, 116-123. https://doi.org/10.1016/j.frl.2019.03.030

Cepoi, C. O. (2020). Asymmetric dependence between stock market returns and news during Covid-19 financial turmoil. Finance Research Letters, 36, 1-5. https://doi.org/10.1016/j.frl.2020.101658

Chang, C. L., McAleer, M., \& Wang, Y. A. (2020). Herding behaviour in energy stock markets during the Global Financial Crisis, SARS, and ongoing Covid-19. Renewable and Sustainable Energy Reviews, 134, 1-15. https:// doi.org/10.1016/j.rser.2020.110349

Chellaswamy, K. P., Natchimuthu, N., \& Faniband, M. (2020). Stock market sensitivity to macroeconomic factors: Evidence from China and India. Asian Economic and Financial Review, 10(2), 146-159. https://doi. org/10.18488/journal.aefr.2020.102.146.159

Chen, M.-H., Demir, E., García-Gómez, C. D., \& Zaremba, A. (2020). The impact of policy responses to Covid-19 on U.S. travel and leisure companies. Annals of Tourism Research Empirical Insights, 1, 1-8. https://doi. org/10.1016/j.annale.2020.100003 
Chiah, M., \& Zhong, A. (2020). Trading from home: The impact of Covid-19 on trading volume around the world. Finance Research Letters, 37. https://doi.org/10.1016/j.frl.2020.101784

Conlon, T., \& McGee, R. (2020). Safe haven or risky hazard? Bitcoin during the Covid-19 bear market. Finance Research Letters, 35(May). https://doi.org/10.1016/j.frl.2020.101607

Contessi, S., \& Pierangelo, D. P. (2020). The international spread of Covid-19 stock market collapses. Finance Research Letters, 101894.

Corbet, S., Goodell, J. W., \& Günay, S. (2020). Co-movements and spillovers of oil and renewable firms under extreme conditions: New evidence from negative WTI prices during Covid-19. Energy Economics, 92, 1-24. https://doi.org/10.1016/j.eneco.2020.104978

Corbet, S., Hou, Y., Hu, Y., Lucey, B., \& Oxley, L. (2020). Aye Corona! The contagion effects of being named Corona during the Covid-19 pandemic. Finance Research Letters, 1-9. https://doi.org/10.1016/j.frl.2020.101591

Corbet, S., Larkin, C., \& Lucey, B. (2020). The contagion effects of the Covid-19 pandemic: Evidence from gold and cryptocurrencies. Finance Research Letters, 35. https://doi.org/10.1016/j.frl.2020.101554

Demir, E., Bilgin, M. H., Karabulut, G., \& Doker, A. C. (2020). The relationship between cryptocurrencies and Covid-19 pandemic. Eurasian Economic Review, 10(3), 349-360. https://doi.org/10.1007/s40822-020-001541

Devpura, N., \& Narayan, P. K. (2020). Hourly oil price volatility: The role of Covid-19. Energy Research Letters, 1, 1-5. https://doi.org/10.46557/001c.13683

du Plooy, S. (2019). On the financial interpretation of risk contributions: An analysis using quantile simulation. Investment Analysts Journal, 48(3), 188-204. https://doi.org/10.1080/10293523.2019.1643126

Dzielinski, M. (2011). News Sensitivity and the Cross-Section of Stock Returns. NCRR Finrisk Working, Paper No. 719.

Espinosa-Méndez, C., \& Arias, J. (2020). Covid-19 effect on herding behaviour in European capital markets. Finance Research Letters. https://doi.org/10.1016/j.frl.2020.101787

Fang, L., \& Peress, J. (2009). Media coverage and the cross-section of stock returns. International Review of Finance, 59(5), 2023-2052. https://doi.org/10.1111/irfi.12191

Fu, M., \& Shen, H. (2020). Covid-19 and corporate performance in the energy industry. Energy Research Letters, 1(1), 1-5. https://doi.org/10.46557/001c.12967

García, D. (2013). Sentiment during recessions. Journal of Finance, 68(3), 1267-1300. https://doi.org/10.1111/ jofi.12027

Ghosh, S. (2020). Asymmetric impact of Covid-19 induced uncertainty on inbound Chinese tourists in Australia: Insights from nonlinear ARDL model. Quantitative Finance and Economics, 4(2), 343-364. https://doi. org/10.3934/qfe.2020016

Groß-Klußmann, A., \& Hautsch, N. (2011). When machines read the news: Using automated text analytics to quantify high frequency news-implied market reactions. Journal of Empirical Finance, 18(2), 321-340. https://doi.org/10.1016/j.jempfin.2010.11.009

Gu, X., Ying, S., Zhang, W., \& Tao, Y. (2020). How do firms respond to Covid-19? First evidence from Suzhou, China. Emerging Markets Finance and Trade, 56(10), 2181-2197. https://doi.org/10.1080/1540496X.2020.1789455 
Guizani, M. (2017). The financial determinants of corporate cash holdings in an oil rich country: Evidence from Kingdom of Saudi Arabia. Borsa Istanbul Review, 17(3), 133-143. https://doi.org/10.1016/j.bir.2017.05.003

Hanna, A. J., Turner, J. D., \&Walker, C. B. (2020). News media and investor sentiment during bull and bear markets. European Journal of Finance. https://doi.org/10.1080/1351847X.2020.1743734

Harjoto, M. A., Rossi, F., Lee, R., \& Sergi, B. S. (2020). How do equity markets react to Covid-19? Evidence from emerging and developed countries. Journal of Economics and Business, 1-15. Retrieved from https:// linkinghub.elsevier.com/retrieve/pii/S0148619520304100

Haroon, O., \& Rizvi, S. A. R. (2020). Covid-19: Media coverage and financial markets behavior-A sectoral inquiry. Journal of Behavioral and Experimental Finance, 27, 1-5. https://doi.org/10.1016/j.jbef.2020.100343

Huang, W., \& Zheng, Y. (2020). Covid-19: Structural changes in the relationship between investor sentiment and crude oil futures price. Energy Research Letters, 1, 2-5. https://doi.org/10.46557/001c.13685

Investing (n.d.). Historical data of indices. Retrieved from https://www.investing.com/

Jeris, S. S., \& Nath, R. D. (2020). Covid-19, oil price and UK economic policy uncertainty: Evidence from the ARDL approach. Quantitative Finance and Economics, 4(3), 503-514. https://doi.org/10.3934/qfe.2020023

Kaczmarek, T., Perez, K., Demir, E., \& Zaremba, A. (2021). How to survive a pandemic: The corporate resiliency of travel and leisure companies to the Covid-19 outbreak. Tourism Management, 84, 1-11.

Karabulut, G., Bilgin, M.H., Demir, E., \& Doker, A. C. (2020). How pandemics affect tourism: International evidence. Annals of Tourism Research, 84. https://doi.org/10.1016/j.annals.2020.102991

Kartal, M. T., Kiliç-Depren, S., \& Depren, Ö. (2020). How main stock exchange indices react to Covid-19 pandemic: Daily evidence from East Asian Countries. Global Economic Review, 1-18. https://doi. org/10.1080/1226508X.2020.1869055

Koenker, R., \& Basset, G. (1978). Regression quantiles. Econometrica, 46(1), 33-50.

Krieger, K., Mauck, N., \& Pruitt, S. W. (2020). The impact of the Covid-19 pandemic on dividends. Finance Research Letters, 101910. https://doi.org/10.1016/j.frl.2020.101910

Mazur, M., Dang, M., \& Vega, M. (2020). Covid-19 and the March 2020 stock market crash. Evidence from S\&P1500. Finance Research Letters, (March), 1-8. https://doi.org/10.1016/j.frl.2020.101690

Mazur, M., Dang, M., \& Vo, T. T. A. (2020). Dividend policy and the Covid-19 crisis. SSRN Electronic Journal. https:// doi.org/10.2139/ssrn.3723790

Mirza, N., Naqvi, B., Rahat, B., \& Rizvi, S. K. A. (2020). Price reaction, volatility timing and funds' performance during Covid-19. Finance Research Letters, 36. https://doi.org/10.1016/j.frl.2020.101657

MSCl-Morgan Stanley Country Index (n.d.). MSCI annual market classification. Retrieved from https://www.msci. com/market-classification

Nicola, M., Alsafi, Z., Sohrabi, C., Kerwan, A., Al-Jabir, A., losifidis, C., ... Agha, R. (2020). The socio-economic implications of the coronavirus pandemic (Covid-19): A review. International Journal of Surgery, 78, 185-193. https://doi.org/10.1016/j.ijsu.2020.04.018

Nguyen, H. M., Vuong, T.H.G., Nguyen, T. H., Wu, Y., \& Wong, W. (2020). Sustainability of both pecking order and trade-off theories in Chinese manufacturing firms. Sustainability, 12, 1-25. 
Okorie, D. I., \& Lin, B. (2020). Stock markets and the Covid-19 fractal contagion effects. Finance Research Letters, (June). https://doi.org/10.1016/j.frl.2020.101640

Pirgaip, B. (2021). Pan(dem)ic reactions in Turkish stock market: Evidence from share repurchases. Eurasian Economic Review. https://doi.org/10.1007/s40822-021-00173-6

Qian, X., Qui, S., \& Zhang, G. (2021). The impact of COVID-19 on housing price: Evidence from China. Finance Research Letters, 1-7. https//doi.org/10.1016/j.frl.2021.101944

Rababah, A., Al-Haddad, L., Sial, M. S., Chunmei, Z., \& Cherian, J. (2020). Analyzing the effects of Covid-19 pandemic on the financial performance of Chinese listed companies. Journal of Public Affairs, 20(4), 1-6. https://doi.org/10.1002/pa.2440

Salisu, A. A., Ebuh, G. U., \& Usman, N. (2020). Revisiting oil-stock nexus during Covid-19 pandemic: Some preliminary results. International Review of Economics and Finance, 69, 280-294. https://doi.org/10.1016/j. iref.2020.06.023

Salisu, A. A., \& Vo, X. V. (2020). Predicting stock returns in the presence of Covid-19 pandemic: The role of health news. International Review of Financial Analysis, 71(June), 1-10. https://doi.org/10.1016/j.irfa.2020.101546

Sergi, B. S., Harjoto, M. A., Rossi, F., \& Lee, R. (2021). Do stock markets love misery? Evidence from the COVID -19. Finance Research Letters.

Shi, Y., \& Ho, K. Y. (2020). News sentiment and states of stock return volatility: Evidence from long memory and discrete choice models. Finance Research Letters, 1-8. https://doi.org/10.36334/modsim.2013.f8.shi

Smales, L. A. (2014a). News sentiment and the investor fear gauge. Finance Research Letters, 11, 122-130. https:// doi.org/10.1016/j.frl.2013.07.003

Smales, L. A. (2014b). Non-scheduled news arrival and high-frequency stock market dynamics. Evidence from the Australian Securities Exchange. Research in International Business and Finance, 32, 122-138. https://doi. org/10.1016/j.ribaf.2014.03.006

Tetlock, P. (2007). Giving content to investor sentiment: The role of media in the stock market. Journal of Finance, 62(3), 1139-1168.

Thorbecke, W. (2020). The impact of the Covid-19 pandemic on the U.S. economy: Evidence from the stock market. Journal of Risk and Financial Management, 13(10), 1-32. https://doi.org/10.3390/jrfm13100233

Topcu, M., \& Gulal, O. S. (2020). The impact of Covid-19 on emerging stock markets. Finance Research Letters, 36(July), 1-4. https://doi.org/10.1080/01694243.2020.1863629

Trinidad \& Tobago Stock Excange (n.d.). Trinidad \& Tobago index data. Retrieved from https://www.stockex.co.tt. Wagner, A. F. (2020). What the stock market tells us about the post-Covid-19 world. Nature Human Behaviour, 4(5), 440-440. https://doi.org/10.1038/s41562-020-0869-y

Yarovaya, L., Mirza, N., Abaidi, J., \& Hasnaoui, A. (2021). Human capital efficiency and equity funds' performance during the Covid-19 pandemic. International Review of Economics and Finance, 71, 584-591. https://doi. org/10.1016/j.iref.2020.09.017

Yilmazkuday, H. (2020). Coronavirus Disease 2019 and the Global Economy. SSRN Electronic Journal. https://doi. org/10.5853/jos.2020.01760 
Zaremba, A., Aharon, D. Y., Demir, E., Kizys, R., \& Zawadka, D. (2021). Covid-19, government policy responses, and stock market liquidity around the world. Research in International Business and Finance, 56, 1-9. https://doi. org/10.2139/ssrn.3631177

Zaremba, A., Kizys, R., Aharon, D. Y., \& Demir, E. (2020). Infected markets: Novel coronavirus, government interventions, and stock return volatility around the globe. Finance Research Letters, 35. https://doi. org/10.1016/j.frl.2020.101597

Zhang, D., Hu, M., \& Ji, Q. (2020). Financial markets under the global pandemic of Covid-19. Finance Research Letters, 36(March). https://doi.org/10.1016/j.frl.2020.101528 


\section{TABLES AND FIGURES}

Table 1: Sample Information about Countries

\begin{tabular}{|c|c|c|c|c|c|}
\hline Country & Index & MSCI Classification & $\begin{array}{c}\text { First Covid-19 } \\
\text { case was } \\
\text { confirmed }\end{array}$ & Obs. & Source \\
\hline Argentina & MERVAL & Emerging & 03.03 .2020 & 28 & Thomson Reuters \\
\hline Australia & ASX 200 & Developed & 26.01 .2020 & 57 & Thomson Reuters \\
\hline Austria & ATX & Developed & 25.02.2020 & 36 & Thomson Reuters \\
\hline Bahrain & BAX & Frontier & 24.02 .2020 & 38 & $\begin{array}{l}\text { https://www. } \\
\text { investing.com }\end{array}$ \\
\hline Bangladesh & DSE 30 & Frontier & 08.03 .2020 & 12 & $\begin{array}{c}\text { https://www. } \\
\text { investing.com }\end{array}$ \\
\hline Belgium & BEL 20 & Developed & 04.02 .2020 & 51 & Thomson Reuters \\
\hline Brazil & BOVESPA & Emerging & 26.02 .2020 & 36 & $\begin{array}{l}\text { https://www. } \\
\text { investing.com }\end{array}$ \\
\hline Bulgaria & BSX Sofia & Standalone & 08.03.2020 & 26 & Thomson Reuters \\
\hline Canada & TSX Composite & Developed & 26.01 .2020 & 57 & Thomson Reuters \\
\hline Chile & CLX IGPA & Emerging & 03.03.2020 & 32 & Thomson Reuters \\
\hline China & Shanghai Composite & Emerging & $22.01 .2020^{1}$ & 54 & Thomson Reuters \\
\hline Colombia & COLCAP & Emerging & 06.03 .2020 & 26 & $\begin{array}{l}\text { https://www. } \\
\text { investing.com }\end{array}$ \\
\hline Cote D'Ivoire & BRVM & Frontier & 11.03 .2020 & 24 & $\begin{array}{c}\text { https://www. } \\
\text { investing.com }\end{array}$ \\
\hline Croatia & CROBEX & Frontier & 25.02 .2020 & 36 & Thomson Reuters \\
\hline Cyprus & Cyprus SE & Unclassified & 09.03 .2020 & 24 & Thomson Reuters \\
\hline Czechia & Prague SE & Emerging & 02.03.2020 & 32 & Thomson Reuters \\
\hline Denmark & OMX Copenhagen 20 & Developed & 27.02.2020 & 33 & Thomson Reuters \\
\hline Egypt & Hermes & Emerging & 14.02 .2020 & 43 & Thomson Reuters \\
\hline Estonia & OMX Tallinn & Frontier & 27.02 .2020 & 34 & Thomson Reuters \\
\hline Finland & OMX Helsinki & Developed & 29.01.2020 & 55 & Thomson Reuters \\
\hline France & CAC 40 & Developed & 26.01.2020 & 57 & Thomson Reuters \\
\hline Germany & DAX 30 & Developed & 28.01.2020 & 56 & Thomson Reuters \\
\hline Greece & ATHEX & Emerging & 26.02 .2020 & 32 & Thomson Reuters \\
\hline Hong Kong & Hang Seng & Developed & 23.01 .2020 & 57 & Thomson Reuters \\
\hline Hungary & BSE & Emerging & 04.03 .2020 & 30 & Thomson Reuters \\
\hline Iceland & OMX Iceland & Standalone & 28.02.2020 & 32 & Thomson Reuters \\
\hline India & Nifty 500 & Emerging & 30.01 .2020 & 50 & Thomson Reuters \\
\hline Indonesia & IDX & Emerging & 02.02 .2020 & 31 & Thomson Reuters \\
\hline Iraq & ISX 60 & Unclassified & 24.02 .2020 & 14 & $\begin{array}{l}\text { https://www. } \\
\text { investing.com }\end{array}$ \\
\hline Ireland & ISEQ Overall & Developed & 29.02 .2020 & 32 & Thomson Reuters \\
\hline Israel & TA 125 & Developed & 21.02.2020 & 34 & Thomson Reuters \\
\hline Italy & FTSE MIB & Developed & 31.01 .2020 & 53 & Thomson Reuters \\
\hline
\end{tabular}




\begin{tabular}{|c|c|c|c|c|c|}
\hline Jamaica & Jamaica SE & Standalone & 11.03 .2020 & 22 & $\begin{array}{l}\text { https://www. } \\
\text { investing.com }\end{array}$ \\
\hline Japan & Nikkei 225 & Developed & 22.01 .2020 & 59 & Thomson Reuters \\
\hline Kazakhstan & KASEX & Frontier & 15.03 .2020 & 21 & $\begin{array}{l}\text { https://www. } \\
\text { investing.com }\end{array}$ \\
\hline Kenya & NSE20 & Frontier & 13.03.2020 & 23 & $\begin{array}{l}\text { https://www. } \\
\text { investing.com }\end{array}$ \\
\hline Kuwait & BKA & Emerging & 24.02 .2020 & 31 & $\begin{array}{l}\text { https://www. } \\
\text { investing.com }\end{array}$ \\
\hline Latvia & OMX RGI & Unclassified & 03.03.2020 & 28 & $\begin{array}{c}\text { https://www. } \\
\text { investing.com }\end{array}$ \\
\hline Lebanon & BLOM & Frontier & 21.02 .2020 & 32 & Thomson Reuters \\
\hline Lithuania & OMX VIL & Frontier & 28.02 .2020 & 31 & $\begin{array}{l}\text { https://www. } \\
\text { investing.com }\end{array}$ \\
\hline Luxembourg & LX SE & Developed & 02.03.2020 & 32 & Thomson Reuters \\
\hline Malaysia & $\mathrm{KLCl}$ & Emerging & 25.01 .2020 & 59 & Thomson Reuters \\
\hline Malta & Malta SE & Standalone & 07.03 .2020 & 25 & Thomson Reuters \\
\hline Mexico & BOLSA & Emerging & 28.02 .2020 & 32 & Thomson Reuters \\
\hline Morocco & Moroccan All Shares & Frontier & 02.03 .2020 & 34 & $\begin{array}{l}\text { https://www. } \\
\text { investing.com }\end{array}$ \\
\hline Netherlands & AEX & Developed & 27.02.2020 & 34 & Thomson Reuters \\
\hline New Zealand & NZX 50 & Developed & 28.02 .2020 & 33 & Thomson Reuters \\
\hline Nigeria & NSE 30 & Frontier & 01.03 .2020 & 33 & $\begin{array}{l}\text { https://www. } \\
\text { investing.com }\end{array}$ \\
\hline Norway & OSBX & Developed & 26.02 .2020 & 34 & $\begin{array}{l}\text { https://www. } \\
\text { investing.com }\end{array}$ \\
\hline Oman & Muscat & Frontier & 24.02 .2020 & 38 & Thomson Reuters \\
\hline Pakistan & Karachi 100 & Emerging & 26.02 .2020 & 36 & Thomson Reuters \\
\hline Peru & BVL & Emerging & 06.03 .2020 & 28 & Thomson Reuters \\
\hline Philippines & IPSEI & Emerging & 30.01 .2020 & 51 & Thomson Reuters \\
\hline Poland & WIG 30 & Emerging & 04.03 .2020 & 30 & $\begin{array}{l}\text { https://www. } \\
\text { investing.com }\end{array}$ \\
\hline Portugal & PSI 20 & Developed & 02.03 .2020 & 32 & Thomson Reuters \\
\hline Qatar & QE General & Emerging & 02.03 .2020 & 33 & $\begin{array}{l}\text { https://www. } \\
\text { investing.com }\end{array}$ \\
\hline Romania & BET & Frontier & 26.02 .2020 & 36 & Thomson Reuters \\
\hline Russia & MOEX & Emerging & 31.01 .2020 & 53 & Thomson Reuters \\
\hline Saudi Arabia & Tadawul & Emerging & 02.03 .2020 & 33 & $\begin{array}{l}\text { https://www. } \\
\text { investing.com }\end{array}$ \\
\hline Serbia & BELEX 15 & Frontier & 08.03.2020 & 29 & $\begin{array}{c}\text { https://www. } \\
\text { investing.com }\end{array}$ \\
\hline Singapore & Straits Time & Developed & 23.01 .2020 & 58 & Thomson Reuters \\
\hline $\begin{array}{l}\text { Slovak } \\
\text { Republic }\end{array}$ & SAX 16 & Unclassified & 06.03 .2020 & 25 & Thomson Reuters \\
\hline Slovenia & SBITOP & Frontier & 05.03 .2020 & 29 & Thomson Reuters \\
\hline South Africa & JSE & Emerging & 05.03.2020 & 29 & Thomson Reuters \\
\hline South Korea & KOSPI & Emerging & 22.02 .2020 & 59 & Thomson Reuters \\
\hline Spain & IBEX 35 & Developed & 01.02 .2020 & 52 & Thomson Reuters \\
\hline
\end{tabular}




\begin{tabular}{|l|c|c|c|c|c|}
\hline Sri Lanka & CSE All Share & Frontier & 27.02 .2020 & 29 & $\begin{array}{c}\text { https://www. } \\
\text { investing.com }\end{array}$ \\
\hline Sweden & OMX Stockholm 30 & Developed & 31.01 .2020 & 53 & Thomson Reuters \\
\hline Switzerland & SMI & Developed & 25.02 .2020 & 36 & Thomson Reuters \\
\hline Taiwan & TSE & Emerging & 22.01 .2020 & 54 & Thomson Reuters \\
\hline Thailand & SET INDEX & Emerging & 22.01 .2020 & 60 & Thomson Reuters \\
\hline $\begin{array}{l}\text { Trinidad \& } \\
\text { Tobago }\end{array}$ & TTSE & Standalone & 16.03 .2020 & 21 & $\begin{array}{c}\text { https://www. } \\
\text { stockex.co.tt }\end{array}$ \\
\hline Tunisia & TUNINDEX & Frontier & 04.03 .2020 & 29 & Thomson Reuters \\
\hline Turkey & BIST 100 & Emerging & 10.03 .2020 & 27 & Thomson Reuters \\
\hline United States & S\&P 500 & Developed & 22.01 .2020 & 60 & Thomson Reuters \\
\hline $\begin{array}{l}\text { United Arab } \\
\text { Emirates }\end{array}$ & ADX & Emerging & 29.01 .2020 & 56 & $\begin{array}{c}\text { https://www. } \\
\text { investing.com }\end{array}$ \\
\hline $\begin{array}{l}\text { United } \\
\text { Kingdom }\end{array}$ & FTSE 100 & Developed & 31.01 .2020 & 53 & Thomson Reuters \\
\hline Ukraine & PFTS & Standalone & 03.03 .2020 & 17 & $\begin{array}{c}\text { https://www. } \\
\text { investing.com }\end{array}$ \\
\hline Venezuela & Venezuela SE & Unclassified & 16.03 .2020 & 21 & Thomson Reuters \\
\hline Vietnam & VrN & 23.01 .2020 & 54 & $\begin{array}{l}\text { https://www. } \\
\text { investing.com }\end{array}$ \\
\hline Total & Frontier & $\mathbf{2 9 9 6}$ & \\
\hline
\end{tabular}

Table 2: Descriptive Statistics

\begin{tabular}{|l|c|c|c|c|c|c|}
\hline VARIABLES & Obs. & Mean & P25 & Median & P75 & Std. Dev. \\
\hline Index Returns & 2996 & -0.004 & -0.017 & -0.0007 & 0.013 & 0.040 \\
\hline Media Hype Index & 2996 & 53.49 & 39.16 & 57.20 & 68.94 & 21.004 \\
\hline Fake News Index & 2996 & 2.19 & 0.76 & 1.38 & 2.41 & 3.661 \\
\hline Country Sentiment Index & 2996 & -18.02 & -27.10 & -13.2 & -5.28 & 18.168 \\
\hline Infodemic Index & 2996 & 53.84 & 35.38 & 55.56 & 71.43 & 22.957 \\
\hline Media Coverage Index & 2996 & 67.00 & 56.03 & 73.06 & 80.35 & 17.622 \\
\hline
\end{tabular}

Table 3: Pairwise Correlation Matrix

\begin{tabular}{|l|c|c|c|c|c|c|c|}
\hline Variables & $\mathbf{1}$ & $\mathbf{2}$ & $\mathbf{3}$ & $\mathbf{4}$ & $\mathbf{5}$ & $\mathbf{6}$ & VIF \\
\hline Index Returns (1) & 1 & & & & & & \\
\hline Media Hype Index (2) & $-0.1438^{*}$ & 1 & & & & & 2.63 \\
\hline Fake News (3) & -0.0028 & 0.2227 & 1 & & & & 1.07 \\
\hline Country Sentiment Index (4) & $0.0363^{*}$ & $-0.0481^{*}$ & -0.0047 & 1 & & & 1.00 \\
\hline Infodemic Index (5) & $-0.1359^{*}$ & $0.2413^{*}$ & 0.0193 & 0,0115 & 1 & & 1.07 \\
\hline Media Coverage Index (6) & $-0.1562^{*}$ & $0.7720^{*}$ & $0.1030^{*}$ & $-0.0495^{*}$ & $0.2049^{*}$ & 1 & 2.48 \\
\hline
\end{tabular}


Table 4: Quantile Regression Results for International Markets

\begin{tabular}{|c|c|c|c|c|c|c|c|}
\hline Variables & $\tau=0.05$ & $\tau=0.10$ & $\tau=0.25$ & $\tau=0.50$ & $\tau=0.75$ & $\tau=0.90$ & $\tau=0.95$ \\
\hline $\begin{array}{l}\text { Media Hype } \\
\text { Index }\end{array}$ & $\begin{array}{c}-0.000514^{* *} \\
(0.000248)\end{array}$ & $\begin{array}{c}-0.00046^{* * *} \\
(0.000109)\end{array}$ & $\begin{array}{c}-0.000198^{* *} \\
(0.000008)\end{array}$ & $\begin{array}{l}-0.00008 \\
(0.00006)\end{array}$ & $\begin{array}{l}-0.00005 \\
(0.00006)\end{array}$ & $\begin{array}{l}-0.000160 \\
(0.000161)\end{array}$ & $\begin{array}{l}-0.000240 \\
(0.000206)\end{array}$ \\
\hline $\begin{array}{l}\text { Fake News } \\
\text { Index }\end{array}$ & $\begin{array}{c}0.000288 \\
(0.000295) \\
\end{array}$ & $\begin{array}{c}0.000489^{* * * *} \\
(0.000114) \\
\end{array}$ & \begin{tabular}{|c|}
$0.000293^{* * * *}$ \\
$(0.000107)$ \\
\end{tabular} & $\begin{array}{c}0.00002 \\
(0.00007) \\
\end{array}$ & $\begin{array}{c}0.00005 \\
(0.000115) \\
\end{array}$ & $\begin{array}{c}-0.00008 \\
(0.000196) \\
\end{array}$ & $\begin{array}{c}0.00008 \\
(0.000357) \\
\end{array}$ \\
\hline $\begin{array}{l}\text { Sentiment } \\
\text { Index }\end{array}$ & $\begin{array}{c}0.000545^{* * * *} \\
(0.000185)\end{array}$ & $\begin{array}{c}0.000311^{* * * *} \\
(0.00009)\end{array}$ & $\begin{array}{c}0.000184^{* *} \\
(0.00008)\end{array}$ & $\begin{array}{c}0.00003 \\
(0.00005)\end{array}$ & $\begin{array}{c}0.00003 \\
(0.00004)\end{array}$ & $\begin{array}{c}0.00005 \\
(0.000109)\end{array}$ & $\begin{array}{c}-0.00009 \\
(0.000274)\end{array}$ \\
\hline $\begin{array}{l}\text { Infodemic } \\
\text { Index }\end{array}$ & $\begin{array}{c}-0.00060^{* * * *} \\
(0.000161)\end{array}$ & $\begin{array}{c}-0.00041^{* * *} \\
(0.000125)\end{array}$ & $\begin{array}{c}-0.00039^{* * *} \\
(0.0006)\end{array}$ & $\begin{array}{c}-0.00019 * * * \\
(0.00003)\end{array}$ & $\begin{array}{c}-0.00025^{* * *} \\
(0.00005)\end{array}$ & $\begin{array}{c}-0.00028^{* * *} \\
(0.00007)\end{array}$ & $\begin{array}{l}-0.00028^{*} \\
(0.000161)\end{array}$ \\
\hline $\begin{array}{l}\text { Media } \\
\text { Coverage } \\
\text { Index }\end{array}$ & $\begin{array}{c}-0.00085^{* * *} \\
(0.000203)\end{array}$ & $\begin{array}{c}-0.00069^{* * *} \\
(0.000159)\end{array}$ & $\begin{array}{l}-0.00051^{* * *} \\
(0.000100)\end{array}$ & $\begin{array}{c}-0.00020^{* * *} \\
(0.00007)\end{array}$ & $\begin{array}{c}-0.00023^{* * *} \\
(0.00009)\end{array}$ & $\begin{array}{c}-0.00008 \\
(0.000245)\end{array}$ & $\begin{array}{l}-0.000294 \\
(0.000302)\end{array}$ \\
\hline Constant & $\begin{array}{l}-0.0542 * * * \\
(0.00250)\end{array}$ & $\begin{array}{c}-0.0379 * * * \\
(0.00123)\end{array}$ & $\begin{array}{l}-0.0165^{* * *} \\
(0.000879)\end{array}$ & $\begin{array}{l}-0.000510 \\
(0.000420)\end{array}$ & $\begin{array}{l}0.0124^{* * *} \\
(0.000500)\end{array}$ & $\begin{array}{l}0.0287^{* * *} \\
(0.00124)\end{array}$ & $\begin{array}{l}0.0450^{* * * *} \\
(0.00211)\end{array}$ \\
\hline Observations & 2996 & 2996 & 2996 & 2996 & 2996 & 2996 & 2996 \\
\hline
\end{tabular}

Table 5: Quantile Regression Results for Developed, Emerging and Frontier Markets

\begin{tabular}{|c|c|c|c|c|c|c|c|}
\hline Variables & $\tau=0.05$ & $\tau=0.10$ & $\tau=0.25$ & $\tau=0.50$ & $\tau=0.75$ & $\tau=0.90$ & $\tau=0.95$ \\
\hline \multicolumn{8}{|c|}{ Panel A. Developed Markets } \\
\hline $\begin{array}{l}\text { Media Hype } \\
\text { Index }\end{array}$ & $\begin{array}{l}-0.000661 \\
(0.000537) \\
\end{array}$ & $\begin{array}{c}0.0005 \\
(0.000443) \\
\end{array}$ & $\begin{array}{c}0.000140 \\
(0.000307) \\
\end{array}$ & $\begin{array}{l}-0.000138 \\
(0.000202) \\
\end{array}$ & $\begin{array}{l}-0.000180 \\
(0.000209) \\
\end{array}$ & $\begin{array}{l}-0.000246 \\
(0.000325) \\
\end{array}$ & $\begin{array}{l}-0.000505 \\
(0.000357) \\
\end{array}$ \\
\hline $\begin{array}{l}\text { Fake News } \\
\text { Index }\end{array}$ & $\begin{array}{l}0.000179 \\
(0.00180) \\
\end{array}$ & $\begin{array}{l}0.000591 \\
(0.00088) \\
\end{array}$ & $\begin{array}{l}-0.000146 \\
(0.000974 \\
\end{array}$ & $\begin{array}{r}-0.000695 \\
(0.00062) \\
\end{array}$ & $\begin{array}{l}-0.00009 \\
(0.00067) \\
\end{array}$ & $\begin{array}{r}-0.000181 \\
(0.00053) \\
\end{array}$ & $\begin{array}{c}0.000378 \\
(0.0011) \\
\end{array}$ \\
\hline & $\begin{array}{c}0.000505 \\
(0.000366) \\
\end{array}$ & $\begin{array}{l}0.000470^{*} \\
(0.000250) \\
\end{array}$ & $\begin{array}{c}0.000262 \\
(0.000184) \\
\end{array}$ & $\begin{array}{c}0.000113 \\
(0.000125) \\
\end{array}$ & $\begin{array}{c}0.000149 \\
(0.000135) \\
\end{array}$ & $\begin{array}{l}0.000572^{* *} \\
(0.000249) \\
\end{array}$ & $\begin{array}{c}0.000723^{*} \\
(0.00040)\end{array}$ \\
\hline $\begin{array}{l}\text { Infodemic } \\
\text { Index }\end{array}$ & $\begin{array}{l}-0.000317 \\
(0.000362) \\
\end{array}$ & \begin{tabular}{|c|}
$-0.000613^{* * *}$ \\
$(0.000243)$ \\
\end{tabular} & $\begin{array}{c}-0.000618^{* * *} \\
(0.000193) \\
\end{array}$ & $\begin{array}{c}-0.000433^{* * * *} \\
(0.000134) \\
\end{array}$ & \begin{tabular}{|c|}
$-0.000332^{* *}$ \\
$(0.000169)$ \\
\end{tabular} & $\begin{array}{l}-0.000402 \\
(0.000349) \\
\end{array}$ & $\begin{array}{c}-0.000802^{* * * *} \\
(0.00024)\end{array}$ \\
\hline $\begin{array}{l}\text { Media } \\
\text { Coverage } \\
\text { Index }\end{array}$ & $\begin{array}{l}-0.00177^{* * * *} \\
(0.000545)\end{array}$ & $\begin{array}{l}-0.00186^{* * *} \\
(0.000476)\end{array}$ & $\begin{array}{l}-0.00139 * * * \\
(0.000387)\end{array}$ & $\begin{array}{l}-0.000594^{* *} \\
(0.000279)\end{array}$ & $\begin{array}{l}-0.000341^{*} \\
(0.000192)\end{array}$ & $\begin{array}{l}-0.000662 \\
(0.000478)\end{array}$ & $\begin{array}{c}-0.000146 \\
(0.00058) \\
\end{array}$ \\
\hline Constant & $\begin{array}{c}-0.0521^{* * *} \\
(0.00368) \\
\end{array}$ & $\begin{array}{c}-0.0385^{* * * *} \\
(0.00188) \\
\end{array}$ & $\begin{array}{c}-0.0175^{* * * *} \\
(0.00175) \\
\end{array}$ & $\begin{array}{c}0.00007 \\
(0.00115) \\
\end{array}$ & $\begin{array}{l}0.0138^{* * *} \\
(0.000929) \\
\end{array}$ & $\begin{array}{l}0.0327^{* * *} \\
(0.00194) \\
\end{array}$ & $\begin{array}{l}0.0482 * * * \\
(0.00223) \\
\end{array}$ \\
\hline Observations & & & & & & & \\
\hline Variables & $\tau=0.05$ & $\tau=0.10$ & & & & $\tau=0.90$ & $\tau=0.95$ \\
\hline \multicolumn{8}{|c|}{ Panel B. Emerging Markets } \\
\hline $\begin{array}{l}\text { Media Hype } \\
\text { Index }\end{array}$ & \begin{tabular}{|c|}
$-0.000878^{* *}$ \\
$(0.000440)$ \\
\end{tabular} & $\begin{array}{c}-0.000540^{* *} \\
(0.000237) \\
\end{array}$ & $\begin{array}{c}-0.000211^{* * *} \\
(0.00008)\end{array}$ & $\begin{array}{l}-0.000177 \\
(0.000111) \\
\end{array}$ & $\begin{array}{l}-0.000110 \\
(0.000104) \\
\end{array}$ & $\begin{array}{l}-0.000392^{* *} \\
(0.000194) \\
\end{array}$ & $\begin{array}{c}-0.000576^{* *} \\
(0.000234) \\
\end{array}$ \\
\hline $\begin{array}{l}\text { Fake News } \\
\text { Index }\end{array}$ & $\begin{array}{l}0.000852 \\
(0.00101) \\
\end{array}$ & $\begin{array}{l}0.000801^{*} \\
(0.000425) \\
\end{array}$ & $\begin{array}{c}0.000355 \\
(0.000299) \\
\end{array}$ & $\begin{array}{c}0.000172 \\
(0.000402) \\
\end{array}$ & $\begin{array}{c}0.000381 \\
(0.000391) \\
\end{array}$ & $\begin{array}{c}0.000398 \\
(0.000621) \\
\end{array}$ & $\begin{array}{l}-0.000247 \\
(0.000581) \\
\end{array}$ \\
\hline $\begin{array}{l}\text { Sentiment } \\
\text { Index }\end{array}$ & $\begin{array}{l}0.000648^{*} \\
(0.000334) \\
\end{array}$ & $\begin{array}{l}0.000432^{* *} \\
(0.000202) \\
\end{array}$ & $\begin{array}{c}0.000120 \\
(0.000215) \\
\end{array}$ & $\begin{array}{c}-0.00003 \\
(0.000159) \\
\end{array}$ & $\begin{array}{c}0.00006 \\
(0.000184) \\
\end{array}$ & $\begin{array}{l}-0.000186 \\
(0.000354) \\
\end{array}$ & $\begin{array}{l}-0.000604 \\
(0.000464) \\
\end{array}$ \\
\hline $\begin{array}{l}\text { Infodemic } \\
\text { Index }\end{array}$ & \begin{tabular}{c|}
$-0.000809 * * *$ \\
$(0.000181)$ \\
\end{tabular} & $\begin{array}{c}-0.000830^{* * * *} \\
(0.000188)\end{array}$ & $\begin{array}{c}-0.000643^{* * * *} \\
(0.000121)\end{array}$ & $\begin{array}{c}-0.000291^{* * * *} \\
(0.00009) \\
\end{array}$ & \begin{tabular}{|c|}
$-0.000389 * * *$ \\
$(0.000112)$ \\
\end{tabular} & $\begin{array}{l}-0.000356 \\
(0.000242) \\
\end{array}$ & $\begin{array}{l}-0.000233 \\
(0.000298) \\
\end{array}$ \\
\hline
\end{tabular}




\begin{tabular}{|c|c|c|c|c|c|c|c|}
\hline $\begin{array}{l}\text { Media } \\
\text { Coverage } \\
\text { Index }\end{array}$ & $\begin{array}{l}-0.00179 * * \\
(0.000761)\end{array}$ & $\begin{array}{c}-0.00143^{* * * *} \\
(0.000441)\end{array}$ & $\begin{array}{l}-0.00103^{* * *} \\
(0.000129)\end{array}$ & $\begin{array}{c}-0.000459^{* * *} \\
(0.000132)\end{array}$ & $\begin{array}{c}-0.000434^{* * *} \\
(0.000147)\end{array}$ & $\begin{array}{l}-0.000103 \\
(0.000453)\end{array}$ & $\begin{array}{c}-0.00008 \\
(0.000670)\end{array}$ \\
\hline Constant & $\begin{array}{c}-0.0588^{* * *} \\
(0.00369)\end{array}$ & $\begin{array}{c}-0.0414^{* * *} \\
(0.00196)\end{array}$ & $\begin{array}{c}-0.0192^{* * *} \\
(0.00151)\end{array}$ & $\begin{array}{l}-0.000316 \\
(0.000816)\end{array}$ & $\begin{array}{l}0.0152^{* * *} \\
(0.00111)\end{array}$ & $\begin{array}{l}0.0335^{* * *} \\
(0.00335)\end{array}$ & $\begin{array}{l}0.0517^{* * *} \\
(0.00315)\end{array}$ \\
\hline Observations & 1066 & 1066 & 1066 & 1066 & 1066 & 1066 & 1066 \\
\hline Variables & $\tau=0.05$ & $\tau=0.10$ & $\tau=0.25$ & $\tau=0.50$ & $\tau=0.75$ & $\tau=0.90$ & $\tau=0.95$ \\
\hline \multicolumn{8}{|c|}{ Panel C. Frontier Markets } \\
\hline $\begin{array}{l}\text { Media Hype } \\
\text { Index }\end{array}$ & $\begin{array}{l}-0.000546 \\
(0.000366) \\
\end{array}$ & $\begin{array}{c}0.00001 \\
(0.000312) \\
\end{array}$ & $\begin{array}{c}-0.00006 \\
(0.000195) \\
\end{array}$ & $\begin{array}{l}-0.00006 \\
(0.00008)\end{array}$ & $\begin{array}{c}-0.000203^{* *} \\
(0.00009)\end{array}$ & $\begin{array}{c}-0.00007 \\
(0.000209) \\
\end{array}$ & $\begin{array}{c}0.00009 \\
(0.000265)\end{array}$ \\
\hline $\begin{array}{l}\text { Fake News } \\
\text { Index }\end{array}$ & $\begin{array}{c}0.000280 \\
(0.000475)\end{array}$ & $\begin{array}{c}-0.00007 \\
(0.000263)\end{array}$ & $\begin{array}{c}0.000165 \\
(0.000178) \\
\end{array}$ & $\begin{array}{c}0.00001 \\
(0.00008)\end{array}$ & $\begin{array}{c}-0.00001 \\
(0.000182)\end{array}$ & $\begin{array}{l}-0.000164 \\
(0.000260)\end{array}$ & $\begin{array}{l}-0.000147 \\
(0.000271) \\
\end{array}$ \\
\hline $\begin{array}{l}\text { Sentiment } \\
\text { Index }\end{array}$ & $\begin{array}{l}0.00204^{* * * *} \\
(0.000619)\end{array}$ & $\begin{array}{c}0.00107^{*} \\
(0.000581)\end{array}$ & $\begin{array}{c}0.000154 \\
(0.000196) \\
\end{array}$ & $\begin{array}{c}0.00008 \\
(0.00008)\end{array}$ & $\begin{array}{l}-0.000283^{*} \\
(0.000162)\end{array}$ & $\begin{array}{l}-0.000244 \\
(0.000272) \\
\end{array}$ & $\begin{array}{l}-0.000498 \\
(0.000380) \\
\end{array}$ \\
\hline $\begin{array}{l}\text { Infodemic } \\
\text { Index }\end{array}$ & $\begin{array}{c}-0.000578^{* * *} \\
(0.000255)\end{array}$ & $\begin{array}{c}-0.000367^{* *} \\
(0.000167) \\
\end{array}$ & $\begin{array}{c}-0.000143^{*} \\
(0.00008)\end{array}$ & $\begin{array}{l}-0.00005 \\
(0.00004)\end{array}$ & $\begin{array}{l}-0.000107 \\
(0.00008)\end{array}$ & $\begin{array}{c}-0.00009 \\
(0.000118) \\
\end{array}$ & $\begin{array}{l}-0.000313^{*} \\
(0.000182)\end{array}$ \\
\hline $\begin{array}{l}\text { Media } \\
\text { Coverage } \\
\text { Index }\end{array}$ & $\begin{array}{l}0.000114 \\
(0.000373)\end{array}$ & $\begin{array}{l}-0.000573^{* *} \\
(0.000228)\end{array}$ & $\begin{array}{l}-0.000218 \\
(0.000229)\end{array}$ & $\begin{array}{c}-0.00003 \\
(0.000111)\end{array}$ & $\begin{array}{c}0.000149 \\
(0.000113)\end{array}$ & $\begin{array}{c}-0.00005 \\
(0.000216)\end{array}$ & $\begin{array}{l}-0.000199 \\
(0.000311)\end{array}$ \\
\hline Constant & $\begin{array}{c}-0.0450^{* * *} \\
(0.00413)\end{array}$ & $\begin{array}{c}-0.0306 * * * \\
(0.00266)\end{array}$ & $\begin{array}{c}-0.0115^{* * *} \\
(0.00104)\end{array}$ & $\begin{array}{l}-0.00117^{* *} \\
(0.000504) \\
\end{array}$ & $\begin{array}{l}0.00706^{* * * *} \\
(0.000958)\end{array}$ & $\begin{array}{l}0.0184^{* * * *} \\
(0.00171)\end{array}$ & $\begin{array}{l}0.0288^{* * * *} \\
(0.00269)\end{array}$ \\
\hline Observations & 561 & 561 & 561 & 561 & 561 & 561 & 561 \\
\hline
\end{tabular}


The Effect of Pandemic News on Stock Market Returns During the Covid-19 Crash: Evidence from...

Table 6: Quantile Regression Results for Europe, Americas, Asia, Middle East and Africa

\begin{tabular}{|c|c|c|c|c|c|c|c|}
\hline Variables & $\tau=0.05$ & $\tau=0.10$ & $\tau=0.25$ & $\tau=0.50$ & $\tau=0.75$ & $\tau=0.90$ & $\tau=0.95$ \\
\hline \multicolumn{8}{|l|}{ Panel A. Europe } \\
\hline $\begin{array}{l}\text { Media Hype } \\
\text { Index }\end{array}$ & $\begin{array}{c}0.00009 \\
(0.000527) \\
\end{array}$ & $\begin{array}{c}0.000143 \\
(0.000350)\end{array}$ & $\begin{array}{c}0.000219 \\
(0.000172)\end{array}$ & $\begin{array}{c}0.00007 \\
(0.000134)\end{array}$ & $\begin{array}{c}-0.00007 \\
(0.000166)\end{array}$ & $\begin{array}{l}-0.000109 \\
(0.000265) \\
\end{array}$ & $\begin{array}{l}-0.000210 \\
(0.000421) \\
\end{array}$ \\
\hline $\begin{array}{l}\text { Fake News } \\
\text { Index }\end{array}$ & $\begin{array}{l}-0.000163 \\
(0.000599) \\
\end{array}$ & $\begin{array}{c}0.00003 \\
(0.000286) \\
\end{array}$ & $\begin{array}{c}0.000109 \\
(0.000128) \\
\end{array}$ & $\begin{array}{l}0.00002 \\
(0.0009) \\
\end{array}$ & $\begin{array}{c}-0.0007 \\
(0.000123) \\
\end{array}$ & $\begin{array}{l}-0.000134 \\
(0.000186) \\
\end{array}$ & $\begin{array}{l}-0.00048^{*} \\
(0.000285)\end{array}$ \\
\hline $\begin{array}{l}\text { Sentiment } \\
\text { Index }\end{array}$ & $\begin{array}{l}0.00104^{* * * *} \\
(0.000333) \\
\end{array}$ & $\begin{array}{l}0.000456^{* *} \\
(0.000223)\end{array}$ & $\begin{array}{c}0.000434^{* * *} \\
(0.000154) \\
\end{array}$ & $\begin{array}{c}0.00005 \\
(0.000105) \\
\end{array}$ & $\begin{array}{l}0.000116 \\
(0.00008)\end{array}$ & $\begin{array}{r}0.00007 \\
(0.000244) \\
\end{array}$ & $\begin{array}{c}0.000144 \\
(0.000479) \\
\end{array}$ \\
\hline $\begin{array}{l}\text { Infodemic } \\
\text { Index }\end{array}$ & $\begin{array}{c}-0.00081^{* * * *} \\
(0.000287) \\
\end{array}$ & $\begin{array}{c}-0.00067^{* * * *} \\
(0.000225) \\
\end{array}$ & $\begin{array}{c}-0.00055^{* * * *} \\
(0.00007) \\
\end{array}$ & $\begin{array}{c}-0.00037^{* * * *} \\
(0.00007) \\
\end{array}$ & $\begin{array}{c}-0.00034^{* * * *} \\
(0.00008) \\
\end{array}$ & $\begin{array}{l}-0.00031^{* * *} \\
(0.000155) \\
\end{array}$ & $\begin{array}{l}-0.00035^{*} \\
(0.000190)\end{array}$ \\
\hline $\begin{array}{l}\text { Media } \\
\text { Coverage Index }\end{array}$ & $\begin{array}{c}-0.00161^{* * *} \\
(0.000532)\end{array}$ & $\begin{array}{c}-0.00141^{* * *} \\
(0.000254)\end{array}$ & $\begin{array}{c}-0.00092^{* * *} \\
(0.000230) \\
\end{array}$ & \begin{tabular}{|c|}
$-0.000332^{* *}$ \\
$(0.000166)$ \\
\end{tabular} & $\begin{array}{l}-0.000195 \\
(0.000221) \\
\end{array}$ & $\begin{array}{c}-0.00003 \\
(0.000372) \\
\end{array}$ & $\begin{array}{l}-0.000196 \\
(0.000561)\end{array}$ \\
\hline Constant & $\begin{array}{l}-0.0558^{* * *} \\
(0.00309) \\
\end{array}$ & $\begin{array}{l}-0.0392^{* * *} \\
(0.00133) \\
\end{array}$ & $\begin{array}{l}-0.0180^{* * *} \\
(0.00168) \\
\end{array}$ & $\begin{array}{c}0.000489 \\
(0.000772) \\
\end{array}$ & $\begin{array}{l}0.0142^{* * *} \\
(0.000857) \\
\end{array}$ & $\begin{array}{l}0.0290^{* * *} \\
(0.00130) \\
\end{array}$ & $\begin{array}{l}0.0456^{* * *} \\
(0.00255)\end{array}$ \\
\hline Observations & & & & & & & \\
\hline Variables & $\tau=0.05$ & & & & & & \\
\hline \multicolumn{8}{|c|}{ Panel B. Americas } \\
\hline $\begin{array}{l}\text { Media Hype } \\
\text { Index }\end{array}$ & $\begin{array}{l}.00109 * * \\
.000499)\end{array}$ & $\begin{array}{l}-0.00106^{* *} \\
(0.000524) \\
\end{array}$ & $\begin{array}{l}-0.000236 \\
(0.000354) \\
\end{array}$ & $\begin{array}{c}0.00009 \\
(0.000232) \\
\end{array}$ & $\begin{array}{c}0.000155 \\
(0.000278) \\
\end{array}$ & $\begin{array}{c}0.000141 \\
(0.000412) \\
\end{array}$ & $\begin{array}{c}0.000600 \\
(0.000640) \\
\end{array}$ \\
\hline $\begin{array}{l}\text { Fake News } \\
\text { Index }\end{array}$ & $\begin{array}{l}0.000648 \\
(0.00277) \\
\end{array}$ & $\begin{array}{r}0.00160 \\
(0.00279) \\
\end{array}$ & $\begin{array}{l}0.000161 \\
(0.00200) \\
\end{array}$ & $\begin{array}{r}-0.000407 \\
(0.00198) \\
\end{array}$ & $\begin{array}{l}0.000350 \\
(0.00235) \\
\end{array}$ & $\begin{array}{r}0.00128 \\
(0.00575) \\
\end{array}$ & $\begin{array}{l}-0.00104 \\
(0.00707) \\
\end{array}$ \\
\hline $\begin{array}{l}\text { Sentime } \\
\text { Index }\end{array}$ & $\begin{array}{c}0.000757 \\
(0.000742) \\
\end{array}$ & $\begin{array}{c}-0.00008 \\
(0.000768) \\
\end{array}$ & $\begin{array}{l}-0.000205 \\
(0.000580) \\
\end{array}$ & $\begin{array}{l}-0.000330 \\
(0.000244) \\
\end{array}$ & $\begin{array}{l}-0.000514 \\
(0.000382) \\
\end{array}$ & $\begin{array}{l}-0.000834^{*} \\
(0.000455) \\
\end{array}$ & $\begin{array}{l}-0.00141 \\
(0.00102) \\
\end{array}$ \\
\hline $\begin{array}{l}\text { Infodemic } \\
\text { Index }\end{array}$ & $\begin{array}{l}-0.00127^{* *} \\
(0.000553) \\
\end{array}$ & $\begin{array}{l}-0.00100^{* *} \\
(0.000414) \\
\end{array}$ & $\begin{array}{c}-0.00093^{* * *} \\
(0.000218) \\
\end{array}$ & $\begin{array}{l}-0.000524^{*} \\
(0.000285) \\
\end{array}$ & $\begin{array}{l}-0.000471 \\
(0.000314) \\
\end{array}$ & $\begin{array}{c}-0.00003 \\
(0.000746) \\
\end{array}$ & $\begin{array}{c}0.00162 \\
(0.00102) \\
\end{array}$ \\
\hline $\begin{array}{l}\text { Media } \\
\text { Coverage Index }\end{array}$ & $\begin{array}{l}-0.000766 \\
(0.000513)\end{array}$ & $\begin{array}{l}-0.000511 \\
(0.000614)\end{array}$ & $\begin{array}{l}-0.00100^{* *} \\
(0.000390)\end{array}$ & $\begin{array}{c}-0.000756^{* *} \\
(0.000315)\end{array}$ & $\begin{array}{l}-0.000565 \\
(0.000398)\end{array}$ & $\begin{array}{c}-0.00109 \\
(0.000698)\end{array}$ & $\begin{array}{l}-0.00179 \\
(0.00165)\end{array}$ \\
\hline Constant & $\begin{array}{c}-0.0704^{* * *} \\
(0.00565) \\
\end{array}$ & $\begin{array}{c}-0.0488^{* * *} \\
(0.00483) \\
\end{array}$ & $\begin{array}{c}-0.0220^{* * *} \\
(0.00320) \\
\end{array}$ & $\begin{array}{l}-0.000419 \\
(0.00244) \\
\end{array}$ & $\begin{array}{l}0.0180 * * * \\
(0.00307) \\
\end{array}$ & $\begin{array}{l}0.0453^{* * *} \\
(0.00879) \\
\end{array}$ & $\begin{array}{l}0.0794^{* * *} \\
(0.0110) \\
\end{array}$ \\
\hline Observ & & & & & & & 363 \\
\hline Variables & & & & $\tau=0.50$ & & & $\tau=0.95$ \\
\hline \multicolumn{8}{|l|}{ Panel C. Asia } \\
\hline $\begin{array}{l}\text { Media Hype } \\
\text { Index }\end{array}$ & $\begin{array}{l}-0.00098^{* * *} \\
(0.000351)\end{array}$ & $\begin{array}{c}-0.00074^{* * * *} \\
(0.000275)\end{array}$ & $\begin{array}{c}-0.000342^{* *} \\
(0.000151) \\
\end{array}$ & $\begin{array}{l}-0.000185 \\
(0.000172) \\
\end{array}$ & $\begin{array}{l}-0.000281^{*} \\
(0.000154)\end{array}$ & $\begin{array}{l}-0.000315 \\
(0.000354) \\
\end{array}$ & $\begin{array}{c}0.000325 \\
(0.000499) \\
\end{array}$ \\
\hline $\begin{array}{l}\text { Fake News } \\
\text { Index }\end{array}$ & $\begin{array}{c}0.00005 \\
(0.00172)\end{array}$ & $\begin{array}{r}-0.000932 \\
(0.00118) \\
\end{array}$ & $\begin{array}{l}-0.000833 \\
(0.000702) \\
\end{array}$ & $\begin{array}{l}-0.000236 \\
(0.000402) \\
\end{array}$ & $\begin{array}{l}-0.000222 \\
(0.000413) \\
\end{array}$ & $\begin{array}{l}0.000415 \\
(0.00119)\end{array}$ & $\begin{array}{r}-0.000979 \\
(0.00138) \\
\end{array}$ \\
\hline $\begin{array}{l}\text { Sentiment } \\
\text { Index }\end{array}$ & $\begin{array}{c}0.000358 \\
(0.000241) \\
\end{array}$ & $\begin{array}{c}0.000242 \\
(0.000178) \\
\end{array}$ & $\begin{array}{c}0.000221 \\
(0.000170)\end{array}$ & $\begin{array}{c}0.00008 \\
(0.000135) \\
\end{array}$ & $\begin{array}{c}0.000104 \\
(0.000127) \\
\end{array}$ & $\begin{array}{c}0.000101 \\
(0.000296) \\
\end{array}$ & $\begin{array}{c}0.000349 \\
(0.000369) \\
\end{array}$ \\
\hline $\begin{array}{l}\text { Infodemic } \\
\text { Index }\end{array}$ & $\begin{array}{l}-0.000595 \\
(0.000445) \\
\end{array}$ & $\begin{array}{c}-0.000458^{* *} \\
(0.000188) \\
\end{array}$ & $\begin{array}{c}0.00001 \\
(0.000210) \\
\end{array}$ & $\begin{array}{c}0.00007 \\
(0.000112) \\
\end{array}$ & $\begin{array}{c}0.000146 \\
(0.000114)\end{array}$ & $\begin{array}{l}0.000326^{*} \\
(0.000189)\end{array}$ & $\begin{array}{c}0.00002 \\
(0.000546)\end{array}$ \\
\hline $\begin{array}{l}\text { Media } \\
\text { Coverage Index }\end{array}$ & $\begin{array}{l}-0.000173 \\
(0.000738)\end{array}$ & $\begin{array}{c}-0.00008 \\
(0.000258)\end{array}$ & $\begin{array}{c}-0.00055^{* * *} \\
(0.000188)\end{array}$ & $\begin{array}{l}-0.000321 \\
(0.000219)\end{array}$ & $\begin{array}{l}-0.000280 \\
(0.000187)\end{array}$ & $\begin{array}{l}-0.000507 \\
(0.000336)\end{array}$ & $\begin{array}{l}-0.000933 \\
(0.000595)\end{array}$ \\
\hline
\end{tabular}




\begin{tabular}{|l|c|c|c|c|c|c|c|}
\hline Constant & $\begin{array}{c}-0.0464^{* * *} \\
(0.00266)\end{array}$ & $\begin{array}{c}-0.0326^{* * *} \\
(0.00224)\end{array}$ & $\begin{array}{c}-0.0133^{* * *} \\
(0.00169)\end{array}$ & $\begin{array}{c}-0.00127 \\
(0.000795)\end{array}$ & $\begin{array}{c}0.00991^{* * *} \\
(0.00109)\end{array}$ & $\begin{array}{c}0.0238^{* * *} \\
(0.00205)\end{array}$ & $\begin{array}{c}0.0405^{* * *} \\
(0.00446)\end{array}$ \\
\hline Observations & 713 & 713 & 713 & 713 & 713 & 713 & 713 \\
\hline
\end{tabular}

Table 6: (continued)

\begin{tabular}{|c|c|c|c|c|c|c|c|}
\hline Variables & $\tau=0.05$ & $\tau=0.10$ & $\tau=0.25$ & $\tau=0.50$ & $\tau=0.75$ & $\tau=0.90$ & $\tau=0.95$ \\
\hline \multicolumn{8}{|c|}{ Panel A. Middle East } \\
\hline $\begin{array}{l}\text { Media Hype } \\
\text { Index }\end{array}$ & $\begin{array}{l}-0.00119 \\
(0.00103)\end{array}$ & $\begin{array}{l}-0.000551 \\
(0.000443)\end{array}$ & $\begin{array}{l}-0.000405 \\
(0.000269)\end{array}$ & $\begin{array}{l}-0.000297^{*} \\
(0.000173)\end{array}$ & $\begin{array}{l}-0.000466^{*} \\
(0.000278)\end{array}$ & $\begin{array}{l}-0.000338 \\
(0.000463)\end{array}$ & $\begin{array}{l}-0.00117^{* *} \\
(0.000465)\end{array}$ \\
\hline $\begin{array}{l}\text { Fake News } \\
\text { Index }\end{array}$ & $\begin{array}{c}0.00131 \\
(0.00225)\end{array}$ & $\begin{array}{l}0.000476 \\
(0.00130)\end{array}$ & $\begin{array}{l}-0.000657 \\
(0.000486)\end{array}$ & $\begin{array}{l}-0.000317 \\
(0.000539)\end{array}$ & $\begin{array}{l}-0.000547 \\
(0.000546)\end{array}$ & $\begin{array}{c}0.000630 \\
(0.000958)\end{array}$ & $\begin{array}{c}0.00295 \\
(0.00191)\end{array}$ \\
\hline $\begin{array}{l}\text { Sentiment } \\
\text { Index }\end{array}$ & $\begin{array}{c}-0.00003 \\
(0.000547) \\
\end{array}$ & $\begin{array}{l}-0.000104 \\
(0.000266) \\
\end{array}$ & $\begin{array}{l}-0.000319 \\
(0.000218) \\
\end{array}$ & $\begin{array}{l}-0.000113 \\
(0.000154) \\
\end{array}$ & $\begin{array}{c}-0.00005 \\
(0.000297) \\
\end{array}$ & $\begin{array}{c}0.00004 \\
(0.000361) \\
\end{array}$ & $\begin{array}{c}0.000296 \\
(0.000648) \\
\end{array}$ \\
\hline $\begin{array}{l}\text { Infodemic } \\
\text { Index }\end{array}$ & $\begin{array}{l}-0.000119 \\
(0.000520) \\
\end{array}$ & $\begin{array}{l}-0.000193 \\
(0.000232) \\
\end{array}$ & $\begin{array}{l}-0.000155 \\
(0.000116) \\
\end{array}$ & $\begin{array}{l}-0.000141 \\
(0.00009) \\
\end{array}$ & $\begin{array}{l}-0.000151 \\
(0.00009) \\
\end{array}$ & $\begin{array}{l}-0.000294 \\
(0.000190) \\
\end{array}$ & $\begin{array}{l}-0.000518 \\
(0.000419) \\
\end{array}$ \\
\hline $\begin{array}{l}\text { Media } \\
\text { Coverage Index }\end{array}$ & $\begin{array}{l}-0.000712 \\
(0.00125) \\
\end{array}$ & $\begin{array}{l}-0.000830 \\
(0.000531) \\
\end{array}$ & $\begin{array}{c}0.00006 \\
(0.000270)\end{array}$ & $\begin{array}{c}0.000105 \\
(0.000229) \\
\end{array}$ & $\begin{array}{l}0.000434^{* *} \\
(0.000220) \\
\end{array}$ & $\begin{array}{c}-0.00006 \\
(0.000527) \\
\end{array}$ & $\begin{array}{c}0.000158 \\
(0.000696) \\
\end{array}$ \\
\hline Constant & $\begin{array}{l}-0.0426 * * * \\
(0.00903)\end{array}$ & $\begin{array}{l}-0.0326^{* * *} \\
(0.00301) \\
\end{array}$ & $\begin{array}{l}-0.0123^{* * *} \\
(0.00267)\end{array}$ & $\begin{array}{l}-0.00255^{* *} \\
(0.00120)\end{array}$ & $\begin{array}{c}0.00721^{* * *} \\
(0.00138) \\
\end{array}$ & $\begin{array}{l}0.0239 * * * \\
(0.00328)\end{array}$ & $\begin{array}{l}0.0415^{* * *} \\
(0.00637) \\
\end{array}$ \\
\hline Observations & 308 & 308 & 308 & 308 & 308 & 308 & 308 \\
\hline Variables & $\tau=0.05$ & $\tau=0.10$ & $\tau=0.25$ & $\tau=0.50$ & $\tau=0.75$ & $\tau=0.90$ & $\tau=0.95$ \\
\hline \multicolumn{8}{|l|}{ Panel B. Africa } \\
\hline $\begin{array}{l}\text { Media Hype } \\
\text { Index }\end{array}$ & $\begin{array}{l}-0.00127 \\
(0.00077)\end{array}$ & $\begin{array}{c}-0.00100^{*} \\
(0.0005)\end{array}$ & $\begin{array}{l}-0.000467 \\
(0.000290)\end{array}$ & $\begin{array}{c}-0.000157 \\
(0.0002)\end{array}$ & $\begin{array}{l}-0.000228 \\
(0.000227) \\
\end{array}$ & $\begin{array}{l}-0.000144 \\
(0.00028)\end{array}$ & $\begin{array}{l}-0.000289 \\
(0.00035) \\
\end{array}$ \\
\hline $\begin{array}{l}\text { Fake News } \\
\text { Index }\end{array}$ & $\begin{array}{l}-0.000980 \\
(0.00238)\end{array}$ & $\begin{array}{l}-0.000779 \\
(0.00149) \\
\end{array}$ & $\begin{array}{l}-0.000696 \\
(0.000814) \\
\end{array}$ & $\begin{array}{l}-0.000321 \\
(0.000293) \\
\end{array}$ & $\begin{array}{c}0.00008 \\
(0.000217) \\
\end{array}$ & $\begin{array}{c}-0.00002 \\
(0.000407)\end{array}$ & $\begin{array}{l}0.000526 \\
(0.00115)\end{array}$ \\
\hline $\begin{array}{l}\text { Sentiment } \\
\text { Index }\end{array}$ & $\begin{array}{c}0.00106 \\
(0.00113) \\
\end{array}$ & $\begin{array}{c}0.00124 \\
(0.000790) \\
\end{array}$ & $\begin{array}{c}0.000648 \\
(0.000481)\end{array}$ & $\begin{array}{c}0.00001 \\
(0.000211) \\
\end{array}$ & $\begin{array}{l}-0.000254 \\
(0.000399) \\
\end{array}$ & $\begin{array}{l}-0.000740^{*} \\
(0.000384)\end{array}$ & $\begin{array}{l}-0.00111^{*} \\
(0.000583)\end{array}$ \\
\hline $\begin{array}{l}\text { Infodemic } \\
\text { Index }\end{array}$ & $\begin{array}{l}-0.000101 \\
(0.000507) \\
\end{array}$ & $\begin{array}{l}-0.000109 \\
(0.000248) \\
\end{array}$ & $\begin{array}{c}-0.00008 \\
(0.000144) \\
\end{array}$ & $\begin{array}{l}-0.00005 \\
(0.00009)\end{array}$ & $\begin{array}{l}-0.000106 \\
(0.000139) \\
\end{array}$ & $\begin{array}{l}-0.000231 \\
(0.000205)\end{array}$ & $\begin{array}{l}-0.000252 \\
(0.000254)\end{array}$ \\
\hline $\begin{array}{l}\text { Media } \\
\text { Coverage Index }\end{array}$ & $\begin{array}{c}0.000539 \\
(0.000979) \\
\end{array}$ & $\begin{array}{c}0.000694 \\
(0.000635) \\
\end{array}$ & $\begin{array}{c}0.000221 \\
(0.000327) \\
\end{array}$ & $\begin{array}{c}0.00008 \\
(0.000171) \\
\end{array}$ & $\begin{array}{c}0.000134 \\
(0.000206) \\
\end{array}$ & $\begin{array}{l}-0.000319 \\
(0.000509) \\
\end{array}$ & $\begin{array}{l}-0.000524 \\
(0.000908) \\
\end{array}$ \\
\hline Constant & $\begin{array}{l}-0.0472^{* * *} \\
(0.00791)\end{array}$ & $\begin{array}{l}-0.0349 * * * \\
(0.00395) \\
\end{array}$ & $\begin{array}{l}-0.0139^{* * *} \\
(0.00217)\end{array}$ & $\begin{array}{c}-0.00282^{* *} \\
(0.00121) \\
\end{array}$ & $\begin{array}{c}0.00699^{* * *} \\
(0.00176)\end{array}$ & $\begin{array}{l}0.0206^{* * *} \\
(0.00419) \\
\end{array}$ & $\begin{array}{l}0.0344^{* * *} \\
(0.00511)\end{array}$ \\
\hline Observations & 244 & 244 & 244 & 244 & 244 & 244 & 244 \\
\hline
\end{tabular}


The Effect of Pandemic News on Stock Market Returns During the Covid-19 Crash: Evidence from...

Table 7: Robust Test of the Equality Slope Estimates across Various Quantile for International Markets

\begin{tabular}{|c|c|c|c|c|c|}
\hline & $\begin{array}{c}\text { Media Hype } \\
\text { Index }\end{array}$ & Fake News Index & Sentiment Index & Infodemic Index & $\begin{array}{c}\text { Media Coverage } \\
\text { Index }\end{array}$ \\
\hline$q[.05-.10]$ & 0.05 & 0.5 & 0.97 & $4.21^{* *}$ & 0.48 \\
\hline$q[.05-.25]$ & 1.84 & 0.01 & 1.95 & 2.11 & 1.41 \\
\hline$q[.05-.50]$ & $3.03 *$ & 0.63 & $3.12^{*}$ & $6.49 * *$ & $3.93 * *$ \\
\hline$q[.05-.75]$ & $3.30 *$ & 0.92 & 2.5 & $3.40^{*}$ & $3.31^{*}$ \\
\hline $\mathrm{q}[.05-.90]$ & 2.07 & 0.53 & 1.79 & $2.96^{*}$ & $4.76^{* *}$ \\
\hline$q[.05-.95]$ & 0.74 & 0.89 & 1.61 & 1.56 & $2.92 *$ \\
\hline $\mathrm{q}[.10-.25]$ & $9.85^{* * *}$ & 1.65 & 1.75 & 0.06 & 1.53 \\
\hline $\mathrm{q}[.10-.50]$ & $13.11^{* * *}$ & $11.07^{* * *}$ & $3.94^{* *}$ & $5.15^{* *}$ & $8.59 * * *$ \\
\hline $\mathrm{q}[.10-.75]$ & $16.16^{* * *}$ & $12.9^{* * *}$ & 2.4 & 1.68 & $5.79^{* * *}$ \\
\hline $\mathrm{q}[.10-.90]$ & $7.63^{* * *}$ & $4.54^{* *}$ & 0.9 & 1.01 & $5.12^{* *}$ \\
\hline$q[.10-.95]$ & 0.99 & $3.94^{* *}$ & 0.61 & 0.5 & $2.75^{*}$ \\
\hline$q[.25-.50]$ & $4.31^{* *}$ & $5.38^{* *}$ & 1.8 & $17.17^{* * *}$ & $13.35^{* * *}$ \\
\hline $\mathrm{q}[.25-.75]$ & $3.37^{*}$ & $4.31^{* *}$ & 0.92 & $4.11^{* *}$ & $4.86^{* *}$ \\
\hline $\mathrm{q}[.25-.90]$ & 0.08 & 0.06 & 0.23 & 0.83 & $3.85^{* *}$ \\
\hline $\mathrm{q}[.25-.95]$ & 0.06 & 1.29 & 0.19 & 0.31 & 1.06 \\
\hline $\mathrm{q}[.50-.75]$ & 0.14 & 0.46 & 0.01 & 1.04 & 0.06 \\
\hline $\mathrm{q}[.50-.90]$ & 0.59 & 0.01 & 0.08 & 0.64 & 0.37 \\
\hline $\mathrm{q}[.50-.95]$ & 0.5 & 0.19 & 0.01 & 0.05 & 0.01 \\
\hline $\mathrm{q}[.75-.90]$ & 1.62 & 0.15 & 0.1 & 0.1 & 0.73 \\
\hline $\mathrm{q}[.75-.95]$ & 0.79 & 0.04 & 0.1 & 0.01 & 0.01 \\
\hline $\mathrm{q}[.90-.95]$ & 0.21 & 0.3 & 0.01 & 0.03 & 0.39 \\
\hline
\end{tabular}

Table 8: Quantile Regression Results for $\mathrm{OECD}^{2}$ Countries

\begin{tabular}{|c|c|c|c|c|c|c|c|}
\hline Variables & $\tau=0.05$ & $\tau=0.10$ & $\tau=0.25$ & $\tau=0.50$ & $\tau=0.75$ & $\tau=0.90$ & $\tau=0.95$ \\
\hline Media Hype Index & $\begin{array}{c}0.000102 \\
(0.000250)\end{array}$ & $\begin{array}{c}0.000125 \\
(0.000216)\end{array}$ & $\begin{array}{c}0.000209 \\
(0.000170)\end{array}$ & $\begin{array}{l}-0.00003 \\
(0.00009) \\
\end{array}$ & $\begin{array}{c}-0.00002 \\
(0.000115) \\
\end{array}$ & $\begin{array}{c}-0.00003 \\
(0.000207) \\
\end{array}$ & $\begin{array}{l}-0.000120 \\
(0.000249) \\
\end{array}$ \\
\hline Fake News Index & $\begin{array}{c}0.00009 \\
(0.000297) \\
\end{array}$ & $\begin{array}{c}0.000192 \\
(0.000233) \\
\end{array}$ & $\begin{array}{c}0.000183 \\
(0.000129) \\
\end{array}$ & $\begin{array}{c}0.00007 \\
(0.000178) \\
\end{array}$ & $\begin{array}{c}0.00007 \\
(0.000166) \\
\end{array}$ & $\begin{array}{l}-0.000102 \\
(0.000183) \\
\end{array}$ & $\begin{array}{l}-0.000484 \\
(0.000320) \\
\end{array}$ \\
\hline Sentiment Index & $\begin{array}{c}0.000610 \\
(0.000389) \\
\end{array}$ & $\begin{array}{c}0.000355 \\
(0.000238) \\
\end{array}$ & $\begin{array}{l}0.000300^{*} \\
(0.000173) \\
\end{array}$ & $\begin{array}{c}0.00007 \\
(0.00006) \\
\end{array}$ & $\begin{array}{l}0.000143 \\
(0.00009) \\
\end{array}$ & $\begin{array}{c}0.000344 \\
(0.000277) \\
\end{array}$ & $\begin{array}{c}0.000330 \\
(0.000330) \\
\end{array}$ \\
\hline Infodemic Index & $\begin{array}{c}-0.00084^{* * *} \\
(0.000157) \\
\end{array}$ & $\begin{array}{c}-0.00079^{* * *} \\
(0.000119) \\
\end{array}$ & $\begin{array}{c}-0.00067^{* * *} \\
(0.00009) \\
\end{array}$ & $\begin{array}{c}-0.00044^{* * *} \\
(0.00007) \\
\end{array}$ & $\begin{array}{c}-0.00041^{* * *} \\
(0.00009) \\
\end{array}$ & $\begin{array}{l}-0.00036^{* *} \\
(0.000161) \\
\end{array}$ & $\begin{array}{c}-0.00062^{* * * *} \\
(0.000202) \\
\end{array}$ \\
\hline $\begin{array}{l}\text { Media Coverage } \\
\text { Index }\end{array}$ & $\begin{array}{c}-0.00207^{* * * *} \\
(0.000421) \\
\end{array}$ & $\begin{array}{c}-0.00158^{* * * *} \\
(0.000221) \\
\end{array}$ & \begin{tabular}{|c|}
$-0.00110^{* * * *}$ \\
$(0.000190)$ \\
\end{tabular} & $\begin{array}{c}-0.00044^{* * * *} \\
(0.000107) \\
\end{array}$ & $\begin{array}{c}-0.000303^{* *} \\
(0.000151) \\
\end{array}$ & $\begin{array}{l}-0.000179 \\
(0.000313) \\
\end{array}$ & $\begin{array}{l}-0.000207 \\
(0.000416) \\
\end{array}$ \\
\hline Constant & $\begin{array}{l}-0.0571^{* * *} \\
(0.00291) \\
\end{array}$ & $\begin{array}{c}-0.0398^{* * * *} \\
(0.00145) \\
\end{array}$ & $\begin{array}{c}-0.0183^{* * * *} \\
(0.00141) \\
\end{array}$ & $\begin{array}{c}0.000316 \\
(0.000862) \\
\end{array}$ & $\begin{array}{l}0.0145^{* * *} \\
(0.000611) \\
\end{array}$ & $\begin{array}{l}0.0316^{* * *} \\
(0.00178) \\
\end{array}$ & $\begin{array}{l}0.0476^{* * *} \\
(0.00178) \\
\end{array}$ \\
\hline Observations & 1444 & 1444 & 1444 & 1444 & 1444 & 1444 & 1444 \\
\hline
\end{tabular}


Table 9: Quantile Regression Results for Standalone and Unclassified Markets

\begin{tabular}{|c|c|c|c|c|c|c|c|}
\hline Variables & $\tau=0.05$ & $\tau=0.10$ & $\tau=0.25$ & $\tau=0.50$ & $\tau=0.75$ & $\tau=0.90$ & $\tau=0.95$ \\
\hline \multirow{2}{*}{$\begin{array}{l}\text { Media Hype } \\
\text { Index }\end{array}$} & -0.00004 & 0.000199 & 0.00004 & -0.00003 & 0.00008 & -0.00007 & 0.00144 \\
\hline & (0.000684) & (0.000287) & (0.000279) & $(0.000121)$ & (0.000214) & (0.000370) & $(0.00123)$ \\
\hline \multirow{2}{*}{$\begin{array}{l}\text { Fake News } \\
\text { Index }\end{array}$} & 0.000302 & 0.00002 & 0.000278 & 0.000109 & -0.00007 & -0.00003 & -0.00117 \\
\hline & $(0.000441)$ & (0.000296) & (0.000224) & (0.000147) & (0.000150) & (0.000284) & (0.000955) \\
\hline \multirow{2}{*}{$\begin{array}{l}\text { Sentiment } \\
\text { Index }\end{array}$} & -0.00152 & -0.00101 & -0.000805 & -0.000222 & -0.000297 & -0.000596 & -0.00313 \\
\hline & $(0.00126)$ & (0.000902) & (0.000569) & $(0.000350)$ & $(0.000506)$ & $(0.00143)$ & $(0.00257)$ \\
\hline \multirow{2}{*}{$\begin{array}{l}\text { Infodemic } \\
\text { Index }\end{array}$} & -0.000427 & $-0.000461^{* *}$ & $-0.000330^{* *}$ & $-0.000201^{* *}$ & -0.000137 & -0.000254 & 0.000144 \\
\hline & $(0.000332)$ & $(0.000194)$ & $(0.000139)$ & (0.00009) & (0.000118) & $(0.000203)$ & $(0.000489)$ \\
\hline \multirow{2}{*}{$\begin{array}{l}\text { Media } \\
\text { Coverage } \\
\text { Index }\end{array}$} & -0.000402 & $-0.000439^{*}$ & -0.000120 & 0.00003 & -0.00009 & 0.000163 & -0.000974 \\
\hline & $(0.000768)$ & $(0.000251)$ & $(0.000249)$ & $(0.00008)$ & $(0.000258)$ & $(0.000557)$ & $(0.00145)$ \\
\hline \multirow{2}{*}{ Constant } & $-0.0345^{* * *}$ & $-0.0243^{* * *}$ & $-0.0115^{* * *}$ & -0.000855 & $0.00872^{* * *}$ & $0.0234^{* * *}$ & $0.0607^{* * *}$ \\
\hline & $(0.00574)$ & $(0.00163)$ & $(0.00178)$ & $(0.000806)$ & $(0.00203)$ & $(0.00636)$ & $(0.0142)$ \\
\hline Observations & 254 & 254 & 254 & 254 & 254 & 254 & 254 \\
\hline
\end{tabular}

Table 10: Definition of Variables

\begin{tabular}{|c|c|c|}
\hline Variables & Description & Source \\
\hline Index Return & $\begin{array}{l}\text { Daily index returns are calculated. } R_{\mathrm{i}, \mathrm{t}}=\left(P_{\mathrm{i}, \mathrm{t}}\right. \\
\left.-P_{\mathrm{i}, \mathrm{t}-\mathrm{t}}\right) / P_{\mathrm{i}, \mathrm{t}-\mathrm{i}} \text { in where } i \text { is the return of the } \\
\text { index at day } t \text {. }\end{array}$ & $\begin{array}{c}\text { Thomson Reuters DataStream and } \\
\text { https://tr.investing.com }\end{array}$ \\
\hline Media Hype Index & $\begin{array}{l}\text { It measures the percentage of news } \\
\text { talking about the coronavirus. Value range } \\
\text { between } 0 \text { and } 100 \text {. }\end{array}$ & https://coronavirus.ravenpack.com/turkey \\
\hline Fake News Index & $\begin{array}{l}\text { It measures the level of media chatter } \\
\text { about the novel virus that makes reference } \\
\text { to misinformation or fake news alongside } \\
\text { Covid-19. The higher the index value, the } \\
\text { more references to fake news found in the } \\
\text { media. }\end{array}$ & https://coronavirus.ravenpack.com/turkey \\
\hline $\begin{array}{l}\text { Country Sentiment } \\
\text { Index }\end{array}$ & $\begin{array}{c}\text { It measures the level of sentiment across } \\
\text { all entities mentioned in the news } \\
\text { alongside the coronavirus. The index } \\
\text { ranges between - } 100 \text { and } 100 \text { where a } \\
\text { value of } 100 \text { is the most positive } \\
\text { sentiment, }-100 \text { is the most negative, and } 0 \\
\text { is neutral. }\end{array}$ & https://coronavirus.ravenpack.com/turkey \\
\hline Infodemic Index & $\begin{array}{c}\text { It measures the percentage of all entities } \\
\text { (places, companies, etc.) that are somehow } \\
\text { linked to Covid-19. Value range between } 0 \\
\text { and } 100 .\end{array}$ & https://coronavirus.ravenpack.com/turkey \\
\hline $\begin{array}{l}\text { Media Coverage } \\
\text { Index }\end{array}$ & $\begin{array}{c}\text { It measures the percentage of all news } \\
\text { sources covering the topic of the novel } \\
\text { coronavirus. Value range between } 0 \text { and } \\
100 .\end{array}$ & https://coronavirus.ravenpack.com/turkey \\
\hline
\end{tabular}


Figure 1: Estimated coefficients of model. Grey line quantile regression (QR) and shaded area (\%95 of QR)
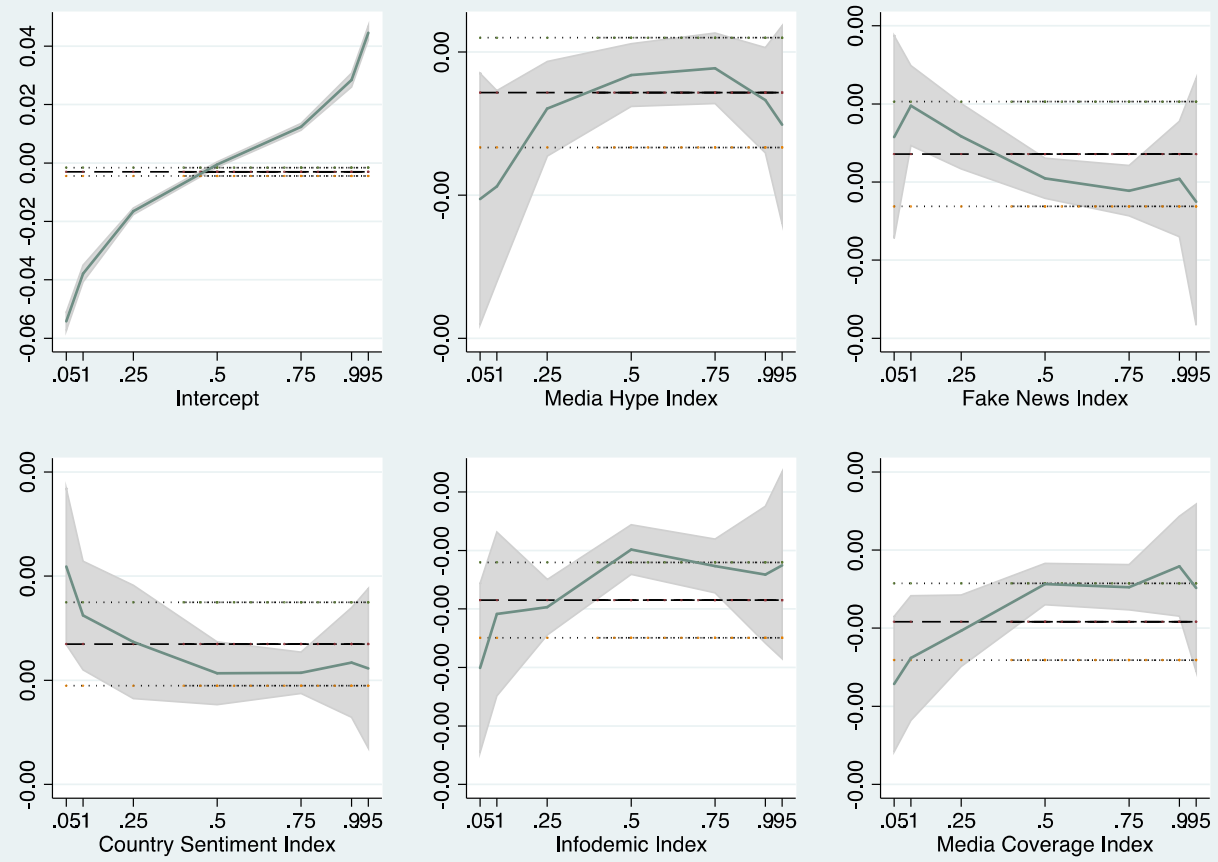